\title{
Genetic Mapping Reveals Complex Architecture and Candidate Genes Involved in Common Bean Response to Meloidogyne Incognita Infection
}

\section{Willian Giordani}

Universidade de Sao Paulo

Henrique Castro Gama

Universidade de Sao Paulo

Alisson Fernando Chiorato

IAC: Instituto Agronomico

João Paulo Rodrigues Marques

Universidade de Sao Paulo

Luis Eduardo Aranha Camargo

Universidade de Sao Paulo

\section{Heqiang Huo}

University of Florida Mid-Florida Research and Education Center

\section{Luciana Lasry Benchimol-Reis}

IAC: Instituto Agronomico

Antonio Augusto Franco Garcia

Universidade de Sao Paulo

Maria Lucia Carneiro Vieira ( $\nabla$ mlcvieir@usp.br)

Universidade de Sao Paulo https://orcid.org/0000-0003-0341-5714

\section{Research Article}

Keywords: Root-knot nematodes, Phaseolus vulgaris, GWAS, QTL mapping, Resistance gene analogs, Reactive oxygen species

Posted Date: March 17th, 2021

DOI: https://doi.org/10.21203/rs.3.rs-305996/v1

License: (c) (1) This work is licensed under a Creative Commons Attribution 4.0 International License.

Read Full License 
Genetic mapping reveals complex architecture and candidate genes involved in common bean response to Meloidogyne incognita infection

Willian Giordani, Henrique Castro Gama, Alisson Fernando Chiorato, João Paulo Rodrigues Marques, Luis Eduardo Aranha Camargo, Heqiang Huo, Luciana Lasry Benchimol-Reis, Antonio Augusto Franco Garcia, Maria Lucia Carneiro Vieira

\title{
Affiliations
}

“Luiz de Queiroz” College of Agriculture, University of São Paulo, Piracicaba, São Paulo, Brazil.

Willian Giordani (ORCID: 0000-0002-1685-1446), Henrique Castro Gama (ORCID: 0000-0002-9149-5955), João Paulo Rodrigues Marques (ORCID: 0000-0001-5052-234X), Luis Eduardo Aranha Camargo (ORCID: 0000-0002-5650-5695), Antonio Augusto Franco Garcia (ORCID: 0000-0003-0634-3277) and Maria Lucia Carneiro Vieira (ORCID: 0000-0003-0341-5714)

Grains and Fibers Center, Agronomic Institute of Campinas, Campinas, São Paulo, Brazil.

Alisson Fernando Chiorato (ORCID: 0000-0002-7004-4717), Luciana Lasry Benchimol-Reis (ORCID: 00000003-1008-5936)

Mid-Florida Research and Education Center, University of Florida, Apopka, FL, United States of America. Heqiang Huo

\section{Corresponding author}

Correspondence to mlcvieir@usp.br

\begin{abstract}
Root-knot nematodes (RKN), particularly Meloidogyne incognita, are among the most damaging and prevalent agricultural pathogens due to their ability to infect roots of almost all crop species, including common bean. The best strategy for their control is through the use of resistant cultivars. However, laborious phenotyping procedures make it difficult to assess nematode resistance in breeding programs. For common bean, this task is especially challenging since little has been done to discover resistance genes or find markers to assist selection. In this study, we performed genome-wide association studies and QTL mapping to explore the genetic architecture and genomic regions underlying the resistance to $M$. incognita and to identify candidate resistance genes. Phenotypic data were collected by a high-throughput assay, and the number of egg masses and root-galling index were evaluated 30 days after inoculation. Complex genetic architecture and independent genomic regions were associated with each trait according to the Fixed and random model Circulating Probability Unification. SNPs located on chromosomes Pv06, Pv07, Pv08 and Pv11 were associated with the number of egg masses, and on Pv01, Pv02, Pv05 and Pv10 with root-galling. A total of 215 candidate genes were identified, including 14 resistance gene analogs and five differentially expressed in a previous RNA-seq analysis. The histochemical analysis indicated that the reactive oxygen species might play a role in the resistance response. Our findings open new perspectives to improve selection efficiency for RKN resistance in common bean, and the candidate genes are valuable targets for functional investigation and gene editing approaches.
\end{abstract}

Keywords: Root-knot nematodes; Phaseolus vulgaris; GWAS; QTL mapping; Resistance gene analogs; Reactive oxygen species.

\section{Declarations}

Funding

This research was funded by the following Brazilian Institutions: Fundação de Amparo à Pesquisa do Estado de São Paulo, grant numbers 2014/06647-9, 2018/09069-7 and 2020/02755-2; Conselho Nacional de Desenvolvimento Científico e Tecnológico, grant numbers 454329/2014-8 and 140588/2018-3; and Coordenação de Aperfeiçoamento de Pessoal de Nível Superior, finance code 001. 
Conflicts of interest/Competing interests

The authors declare that they have no conflict of interest.

Ethics approval

Not applicable.

Consent to participate

Not applicable.

Consent for publication

Not applicable.

Availability of data and material

GBS data can be accessed at the GenBank database, BioSamples SAMN05513252 and SAMN05513251, included in BioProject PRJNA336556. RNA-seq libraries can be obtained under accession number PRJNA288189. Phenotypic data are available by contacting the corresponding author, Maria Lucia Carneiro Vieira, by email: mlcvieir@usp.br

Code availability

Not applicable.

Authors' contributions

Conceptualization: WG and MLCV; Methodology: WG, JPRM and HCG; Formal analysis: WG, HCG and AAFG; Investigation: WG and HCG; Resources: AFC, LLB-R and MLCV; Writing - original draft: WG and HCG; Writing - review \& editing: WG, HH, LEAC, AAFG and MLCV; Supervision: MLCV; Project administration: MLCV; Funding Acquisition: MLCV.

Key message

GWAS, QTL mapping and candidate genes associated with RKN reproduction and the severity of root-galling provide insights into the complex genetic architecture of the common bean response to Meloidogyne incognita infection.

\section{Acknowledgments}

The authors wish to thank the following Brazilian Institutions: Fundação de Amparo à Pesquisa do Estado de São Paulo (FAPESP; grant number 2014/06647-9, 2018/09069-7 and 2020/02755-2); Conselho Nacional de Desenvolvimento Científico e Tecnológico (CNPq; grant number 454329/2014-8); and Coordenação de Aperfeiçoamento de Pessoal de Nível Superior (CAPES, Finance Code 001) for financial support. We also thank Carlos A. de Oliveira for technical assistance, Professor Mario Massayuki Inomoto (University of São Paulo) for providing the nematode inoculum and Mr. Steve Simmons for proofreading the manuscript.

\section{Introduction}

The common bean (Phaseolus vulgaris) is the main legume grain consumed directly by humans (Broughton et al. 2003; Bellucci et al. 2014), and global annual production stands at 31 million metric tons (Faostat 2018). It is currently a staple food for more than 300 million people in Eastern Africa and Latin America, accounting for up to $65 \%$ of protein and $32 \%$ of energy intake (Gepts et al. 2008; Blair et al. 2010; Petry et al. 2015).

The evolutionary history and domestication process of $P$. vulgaris are particularly unique and well-studied. Originating in Mexico (Bitocchi et al. 2012, 2013), the species spread to South America, resulting in the formation of two gene pools: the Mesoamerican and the Andean (Gepts et al. 1986; Koinange and Gepts 1992). Domestication then occurred in at least two independent events that have been defined according to the seed phaseolin type (Gepts et al. 1986), allozymes (Koenig and Gepts 1989; Singh et al. 1991), plant morphology (Gepts and Debouck 1991; Singh et al. 1991), chloroplast (Chacón et al. 2005) and nuclear DNA polymorphisms (Hanai et al. 2007; Kwak and Gepts 2009; Rossi et al. 2009; Bitocchi et al. 2013; Rodriguez et al. 2016). Importantly, these findings provided a knowledge base helping in the conservation and use of the available germplasm (Bitocchi et al. 2017).

Root-knot nematodes (RKN; Meloidogyne spp.) are among the most devastating pathogens for many crop species, including common bean. Among more than 90 species, M. incognita is extremely widespread, especially in tropical regions. It is considered perhaps the single most damaging pathogen for global agriculture (Trudgill and Blok 2001). As biotrophic pathogens, RKN feed only on living cells, requiring an intimate relationship with 
their hosts. After invading the root vascular cylinder, second-stage juveniles (J2s) induce root cell differentiation into specialized, giant nurse cells, engendering the typical symptom of root-galling (Abad et al. 2009).

Although they rarely lead to plant death, attacks by RKN cause severe damage to the root system, resulting in reduced nutrient and water uptake and symptoms of stunted growth, wilting, and chlorosis (Lilley et al. 2011). Additionally, the injury caused by nematode infection might increase plant susceptibility to other biotic and abiotic stresses (Caromel and Gebhardt 2011). As a consequence, yield loss in susceptible crops can exceed 20\%, especially in developing countries where subsistence farmers crop common bean under low-input systems and can suffer yield losses of up to 90\% (Atkinson et al. 1995; Koenning et al. 1999; Abawi et al. 2005).

RKN control strategies are usually impracticable and ineffective under field conditions. The nematode attacks a wide range of hosts, and therefore practices such as crop rotation are not effective methods for suppressing Meloidogyne spp. (Nyczepir and Thomas 2009; Coyne and Affokpon 2018). Furthermore, the development of an alternative control approach has become even more pressing due to the ban on the use of nematicides in the interests of environmental protection (Lilley et al. 2011). Thus, the efforts of breeders to develop resistant cultivars are essential from economical, practical and environmental perspectives.

Anyway, the complex and laborious phenotyping procedures have made it difficult to consolidate an effective and reliable protocol for assessing nematode resistance in breeding programs. Over the past few years several common bean genotypes have been evaluated, but none has proved fully resistant to M. incognita (Alves et al. 2011; Santos et al. 2012; Bozbuga et al. 2015; Costa et al. 2019). Moreover, in contrast to what has been achieved in the Solanaceae, where some Meloidogyne resistance genes are extensively used by breeders and farmers (Dropkin 1969; Messeguer et al. 1991; Yaghoobi et al. 1995; Williamson 1998), for most crop species, the identification and functional characterization of the genetic factors involved into controlling RKN resistance remain elusive, hence the importance of conducting studies aimed at dissecting the genetic architecture of host responses and identifying the genes underlying the resistance (Singh and Schwartz 2011).

In one of the pioneering efforts towards elucidating the P. vulgaris-M. incognita interaction, Santini et al. (2015) carried out a transcriptome analysis of a moderately susceptible cultivar at 4 and 10 days after inoculation (DAI). The authors reported 797 root differentially expressed genes, evidencing the complex common bean response mechanisms. Although RNA-seq technology can provide insights regarding the genes and pathways involved in the host response to the pathogen (Westermann et al. 2012), it does not allow measurement of the effect of each gene on the phenotypic variation, which is essential for breeding.

Since the development of genetic markers based on DNA, genes and quantitative trait loci (QTL) involved in the response to root-knot nematodes have been mapped in different plant species (Caromel and Gebhardt 2011). In the traditional QTL mapping approaches, DNA polymorphisms are identified in a biparental segregating population, and the recombination generated in each meiotic event allows detection of loci segregating jointly with the phenotypic variation of a given trait. The advent of low-cost next generation sequencing methods has given rise to genome-wide association studies (GWAS), also known as association mapping, as powerful tools for identifying genotype-phenotype associations. Since it is not necessary to create a segregating population and due to its higher resolution, this technique has been successfully applied in plant breeding, dissecting the complex architecture of quantitative traits as well as identifying genomic regions underlying phenotypic variation (Zhu et al. 2008; Korte and Farlow 2013; Huang and Han 2014). 
In this study, we performed GWAS on a core collection to dissect the genetic architecture and identify genomic regions and candidate genes underlying the common bean response to $M$. incognita infection. Additionally, QTL mapping was conducted in a biparental $\mathrm{BC}_{2} \mathrm{~F}_{4}$ population with the aim of validating the SNPtrait associations. Finally, we carried out preliminary histochemical analysis to indicate the potential involvement of reactive oxygen species (ROS) in the resistance response.

\section{Materials and methods}

\section{Plant material}

The GWAS were based on a panel of 180 common bean genotypes representative of the genetic diversity in the common bean germplasm repository (1800 accessions) at the Agronomic Institute of Campinas (IAC), Brazil (Perseguini et al. 2015). The IAC common bean gene bank is one of the largest in Brazil and its core collection panel is renowned for its variability in terms of seed morphology, resistance to biotic and abiotic stresses and grain nutrient composition (Perseguini et al. 2015; Diniz et al. 2019). Still, it was previously classified according to the institution of origin, type of phaseolin (27 T-type for Andean and $153 \mathrm{~S}$-type for Mesoamerican gene pools), seed size and commercial group (Diniz et al. 2019).

For validation by QTL mapping, we used a $\mathrm{BC}_{2} \mathrm{~F}_{4}$ population of 91 individuals. This population was previously generated by crossing donor accession AND-277 and recurrent cultivar IAC-Milênio. After two backcrosses, the plants were self-pollinated for three generations to obtain a set of $\mathrm{BC}_{2} \mathrm{~F}_{4}$ lines. Originally designed to map QTLs to the angular leaf spot pathogen (Pseudocercospora griseola), the phenotypic contrast between the genitors in terms of the number of egg masses and root-galling index (Online Resource 1) suggested that they could be used for QTL analysis related to the common bean reaction to M. incognita.

\section{Phenotypic data}

Phenotypic data were collected by a throughput assay, in the absence of soil, using the seedling growth pouches method described in Atamian et al. (2012) with minor adaptations. Briefly, seeds were pre-germinated in a biochemical oxygen demand (BOD) incubator at $28^{\circ} \mathrm{C}$ for 6 days and the seedlings transferred to plastic zipper bags $(24 \times 17 \mathrm{~cm})$ containing a germination paper. The pouches were placed in a controlled-environment chamber in an upright position and kept at $25-28{ }^{\circ} \mathrm{C}$ under a $16 / 8$ (light/dark) photoperiod. The plants were watered daily with autoclaved distilled water and inoculated with 1,500 J2s when the tertiary root tips emerged.

The population of $M$. incognita race 3 was initially collected from a cotton field in the Midwest region of

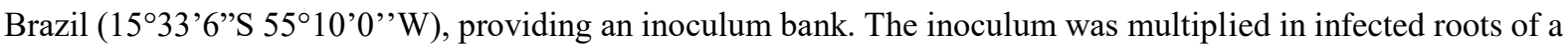
susceptible line of tomato (Solanum lycopersicum - Santa ClaraVF5600, Sakata) that were grown under greenhouse conditions for 60 days. To extract nematode eggs, the tomato roots were well-washed, cut and shaken for $2 \mathrm{~min}$ in $500 \mathrm{~mL}$ of $10 \% \mathrm{NaOCl}$ solution. The solution was poured through a set of 425, 90 and $25 \mu \mathrm{m}$ sieves in order to retain the eggs. After removing the excess $\mathrm{NaOCl}$ with distilled water, the eggs were collected and placed onto double layer disposable wipes (Kimwipe, Sigma-Aldrich) fitted over a metal basket inside a Petri dish. After 5 to 8 days, the freshly hatched J2s that passed through the paper were collected. The juveniles were counted using a Peters slide under an optical microscope and the inoculation solution prepared by dilution, resulting in a final concentration of $300 \mathrm{~J} 2 \mathrm{~s}$ per $\mathrm{mL}$. 
To perform the inoculation, the plants were placed horizontally and the roots evenly infused with $1500 \mathrm{~J} 2 \mathrm{~s}$ in $5 \mathrm{~mL}$ of solution. After $24 \mathrm{~h}$ in the dark, the plants were moved to the growth chamber, being irrigated daily with water, and weekly with half-strength Hoagland's nutritive solution (Hoagland and Arnon 1950). Thirty DAI, each pouch was infused with $15 \mathrm{~mL}$ of erioglaucine dye $\left(75 \mathrm{mg} \mathrm{L}^{-1}\right)$ for $12 \mathrm{~h}$ to facilitate counting the number of egg masses per root system under a stereoscope (10 x magnifier). Root-galling symptoms were indexed based on the Bridge and Page (1980) scale. The experiments were performed in randomized complete block design with five replicates for the IAC core collection panel (GWAS) and four replicates for the $\mathrm{BC}_{2} \mathrm{~F}_{4}$ population (QTL mapping), each block forming an independent run of the experiment carried out over time.

Linear mixed models were fitted to estimate the generalized measurement of heritability, find the adjusted means to map QTLs, obtain genetic correlations among traits, and rank genotypes for selection. For the IAC core collection panel, the phenotypic data acquired for number of egg masses and root-galling index were analyzed according to the following statistical model:

$$
Y_{i j k}=\mu+\beta_{j}+\tau_{\mathrm{i}(\mathrm{k})}+\rho_{k}+\varepsilon_{i j k}
$$

where: $Y_{i j k}$ is the phenotypic value of genotype $i$ within gene pool $k$ in block $j ; \mu$ is an intercept; $\beta_{j}$ is the random effect of block $j$, where $\beta_{j} \sim N\left(0, \sigma_{\beta}^{2}\right) ; \tau_{i(k)}$ is the random effect of genotype $i$ within gene pool $k$, where $\tau_{\mathrm{i}(\mathrm{k})} \sim N\left(0, \sigma_{\tau}^{2}\right) ; \rho_{k}$ is the fixed effect of gene pool $k$; and $\varepsilon_{i j k}$ is the experimental error associated with genotype $i$ in block $j$ within gene pool $k$, where $\varepsilon_{i j k} \sim N\left(0, \sigma^{2}\right)$. For the $\mathrm{BC}_{2} \mathrm{~F}_{4}$ population, the model was similar but with no modeling for the gene pool effect.

The ASReml-R package (Butler et al. 2009) was used to carry out linear mixed-model analysis. Wald and likehood ratio tests (LRT) were performed to verify the respective statistical significance of random and fixed effects. The best linear unbiased predictors (BLUP) obtained for the genotypic factor were used to calculate the genotypic correlations using Pearson's coefficient. Because of the unbalanced condition, that is typical when evaluating a large number of genotypes and repetitions, the generalized measurement of heritability was computed according to Cullis et al. (2006), using the following expression:

$$
H_{c}^{2}=1-\frac{v B L U P}{2 \hat{\sigma}_{\tau}^{2}}
$$

where: $H_{c}^{2}$ is the heritability; $v B L U P$ the variance of the average difference between two BLUPs, and $\hat{\sigma}_{\tau}^{2}$ the genetic variance. Coefficient of genetic variation $\left(\mathrm{CV}_{\mathrm{g}}\right)$ for each trait was calculated as $C V_{g}=\frac{\sigma_{\tau}}{\bar{x}}$, where $\sigma_{\tau}$ is the square root of the estimated genetic variance and $\bar{x}$ the respective mean value.

\section{Genotypic data}

The IAC core collection panel was previously genotyped by the genotyping by sequencing (GBS) approach at the Genomic Diversity Facility of the Cornell University's Institute of Biotechnology, as described by Diniz et al. (2019). In brief, DNA extracted from young leaves was digested with ApeKI enzyme and barcoded adapters were ligated to digested fragments, which were pooled and amplified by PCR as described by Elshire et al. (2011). Single-end sequencing was performed with the HiSeq 2500 platform (Illumina, San Diego, CA, USA). The sequence reads with $\sim 100$ nt from two DNA libraries are available in the GenBank database, BioSample SAMN05513252 and SAMN05513251, both included in BioProject PRJNA336556. SNP calling was performed using the TASSEL-GBS bioinformatics pipeline and the SNP data were curated based on minor allele frequency 
$(M A F) \geq 0.05$; minimum coefficient of inbreeding of 0.9 and call rate of $<0.9$. SNPs. Heterozygous loci were set as missing data. Finally, a total of 10,362 SNPs were identified and can be accessed in Diniz et al. (2019).

The genotypic data used for QTL mapping were obtained from the $\mathrm{BC}_{2} \mathrm{~F}_{3}$ generation. To do this, DNA was extracted from young leaves and converted into NExtRAD (Nextera-tagmented reductively-amplified DNA) libraries by SNPsaurus LLC (Eugene, Oregon, USA). The libraries were sequenced on the HiSeq4000 platform with 150 bp paired-end sequencing. Reads were demultiplexed and pre-processed by SNPsaurus, followed by assembly, mapping and SNP identification according to the standard workflow. SNPs were further filtered based on $4 \mathrm{x}$ minimum covered, MAF $\geq 0.01$ and a call rate $<0.8$ using vcftools software v.0.1.15. Heterozygous loci were eliminated to allow the use of phenotypic data from advanced generations without altering the expected recombination frequency.

\section{GWAS}

To reveal SNPs associated with the number of egg masses and root-galling index, GWAS were conducted according to the Fixed and random model Circulating Probability Unification (FarmCPU; Liu et al. 2016) and implemented in the GAPIT - R package (Lipka et al. 2012). The strategy used by the FarmCPU model is to separate the Multiple Loci Linear Mixed Model (MLMM) into two iterative stages: a Fixed Effect Model (FEM) and a Random Effect Model (REM). In the FEM stage, each marker is tested and pseudo-QTNs (quantitative trait nucleotides) included as covariates to control false-positives and false-negatives. In the REM stage, multiple associated markers are used to obtain kinship and optimize the selection of pseudo-QTNs, preventing model overfitting. In each iteration, the p-values of individual testing markers and multiple associated markers are unified (Liu et al. 2016). Thus, FEM and REM can be written as:

$$
\begin{aligned}
& \text { FEM: } y_{i}=M_{i 1} b_{1}+M_{i 2} b_{2}+\cdots+M_{i t} b_{t}+S_{i j} d_{j}+\varepsilon_{i} \\
& \text { REM: } y_{i}=u_{i}+\varepsilon_{i}
\end{aligned}
$$

In both models, $y_{i}$ is the trait adjusted mean for the $i$ th common bean accession and $\varepsilon_{i}$ corresponds to the residual $\sim \mathrm{N}\left(0, \sigma_{e}^{2}\right)$, where $\mathrm{N}$ is a normal distribution. In the FEM, $M_{i 1}, M_{i 2}, \ldots, M_{i t}$ and $b_{1}, b_{2}, \ldots, b_{j}$ are the $i$ th and $t$ th pseudo-QTNs corresponding respectively to genotype and effect (in the first interaction there was no pseudo-QTN); $S_{i j}$ is the genotype of the $i$ th common bean accession and the $j$ th SNP marker, and $d_{j}$ is the effect of the $j$ th SNP marker. In the REM, $u_{i}$ is the total genetic effect of the $i$ th common bean accession, in which the variance and covariance matrix of the genetic effects is given by $G=2 K \sigma_{a}^{2}$, where $K$ is the kinship matrix based on the pseudo-QTNs and $\sigma_{a}^{2}$ the genetic variance.

The associations were tested for the 10,362 SNP markers and the adjusted means of each trait were obtained as described in the previous phenotypic model, but treating genotype as a fixed effect to obtain the best linear unbiased estimators (BLUEs) in order to avoid a double-shrinkage. The threshold for detecting significant SNPs was determined by Bonferroni multiple test correction $(\mathrm{p}<4.82 \mathrm{e}-06)$ and by permutation tests using 1000 iterations, both at $5 \%$ of global significance for type I error.

The proportion of variance explained (PVE) by each SNP-trait association was estimated according to

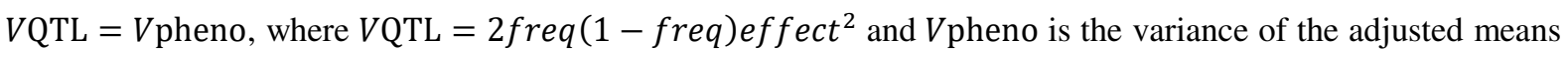
for each trait.

\section{QTL mapping}


To perform QTL mapping, a linkage map previously constructed for a $\mathrm{BC}_{2} \mathrm{~F}_{3}$ population was used. Importantly, this map was built using the software OneMap v2.1.3 (Margarido et al. 2007), which was modified to fit the genetic structure of this specific population (Almeida et al. 2020; unpublished). In brief, markers were tested for the expected Mendelian frequencies (1/8:7/8), and those exhibiting segregation distortion were excluded. The grid search algorithm was adapted to compute the recombination fraction expected for the population. Linkage groups were defined according to the recombination fractions and physical position on the reference genome. Ordination was established using the compare, try and $m d s$ algorithms in several runs. Markers were also manually adjusted based on heatmap analysis. After ordination, the recombination fractions were reestimated using the Multipoint Hidden Markov models. We also attempted to insert SNPs with no chromosomic position using the try algorithm and in case of success, the Multipoint Hidden Markov models were recalculated. Finally, a map of 1,093 SNPs assigned to 11 linkage groups, totaling $1114 \mathrm{cM}$, was obtained (Online Resource 2).

QTL analysis of the number of egg masses and root-galling index was carried out using the R/qtl package (Broman et al. 2003). Initial interval mapping was performed with the scanone function, using Haley-Knott regression to find an adequate number of cofactors. Composite interval mapping (CIM; Zeng 1994) was then applied to scan for QTLs at a step size of $1 \mathrm{cM}$ and window size of $25 \mathrm{cM}$ using the cim function with 4 cofactors by both Haley-Knott and Expectation-Maximization (EM) regression algorithms. An empirical genome-wide threshold was determined based on the 90th percentile of 1,000 permutations for each trait (Churchill and Doerge 1994). To estimate the PVE for significant QTLs and the allelic effects, analysis of variance was fitted to the data using the fitqtl function.

\section{Searching for candidate genes}

The search for host candidate genes putatively involved in the response to nematode infection was carried out within the genomic loci in linkage disequilibrium (LD) with the significant SNPs according to the GWAS results. LD was calculated as the squared coefficient of correlation $\left(r^{2}\right)$ between each pair of markers using the LDheatmap R-package (Shin et al. 2006), and the following expression:

$$
r^{2}=\frac{\left(P_{A B}-P_{A} P_{B}\right)^{2}}{P_{A}\left(1-P_{A}\right) P_{B}\left(1-P_{B}\right)}
$$

where: $P_{A}$ is the allele frequency of $\mathrm{A} ; P_{B}$ is the allele frequency of $\mathrm{B}$, and $P_{A B}$ is the allele frequency of haplotype $\mathrm{AB}$. The genomic region browsed for candidate genes was defined based on the LD block in which the significant SNP was located $\left(r^{2}>0.2\right)$, similar to the approach proposed by Assefa et al. (2019).

The $P$. vulgaris genome sequence (Schmutz et al. 2014) available on the NCBI Assembly database was used to obtain the protein sequences of the respective coding genes at the genomic intervals. These sequences were examined for similarity with sequences deposited in the RefSeq database (O'Leary et al. 2015) using the BLASTp tool in Blast2GO v.5 (Conesa et al. 2005), with an e-value cutoff of $1 \times 10^{-5}$. Gene ontology (GO) mapping and annotation were run using the same software with default parameters. In addition, GO terms enrichment was performed employing singular enrichment analysis, implemented on the AgriGO v.2.0 platform (Tian et al. 2017) according to Fisher's exact test $(\alpha=0,05)$.

To narrow down the number of candidate genes, we initially took into consideration the genes expressed in roots of the Jamapa cultivar according to the common bean expression atlas available on the PvGEA platform 
(O'Rourke et al. 2014). The expression profile of whole roots collected at the second trifoliate stage was used as a reference. Furthermore, candidate genes were also selected among those previously identified by Santini et al. (2016) as differentially expressed during the P. vulgaris - M. incognita interaction by RNA-seq analysis. Briefly, this study assessed the root tissue transcriptome of the Brazilian cultivar IPR-Saracura at 4 and 10 DAI, respectively equivalent to the stages of nematode penetration and giant nurse cell development. Sequencing libraries were constructed following the TruSeq RNA Sample Preparation v2 protocols (Illumina, San Diego, USA) and paired-end sequencing was performed on the MiSeq platform (Illumina, San Diego, USA), generating 101 bp reads. After alignment with the common bean reference genome (Schmutz et al. 2014), around 327 million reads were mapped to 27,195 unigenes, which were tested for differential expression. The raw data can be accessed in the NCBI database, Bioproject PRJNA288189.

Finally, aiming to predict the presence of resistance gene analogs (RGA), the protein sequences and their isoforms were subjected to a search for conserved protein domains, using the Hidden Markov Model profile, through the PFAM platform (El-Gebali et al. 2019) and a threshold e-value $\leq 1 \times 10-5$. The following conserved domains were considered: Nucleotide binding-ARC (NB-ARC), Leucine-rich repeats (LRR), Transmembrane (TM), Coiled-coil (CC), Toll/interleukin-1 receptor (TIR) and Protein kinase (Pkinase), related to NBS-LRR and TM-LRR classes and their variations, which are often related to molecular mechanisms of pathogen recognition in plants.

\section{Histochemical analysis of $\mathrm{H}_{2} \mathrm{O}_{2}$}

Aiming to move forward and provide preliminary evidence of pathways involved in the common bean response to $M$. incognita, histochemical analysis was conducted to examine if inoculation triggered any sign of root ROS accumulation, particularly hydrogen peroxide $\left(\mathrm{H}_{2} \mathrm{O}_{2}\right)$, in roots. Next, we investigated how M. incognita inoculation affected ROS status of five genotypes: two moderately resistant (IAC-Tybatã and Puebla-152-CIAT); two highly susceptible (TB-01-13 and Jamapa-CIAT-1671) and one previously classified as moderately susceptible (IPR-Saracura), formerly used to transcriptome analysis by Santini et al. (2015).

Plants were inoculated in growth pouches as described above, but at a higher inoculum concentration (6.000 J2s). Control samples were mock-inoculated with distillated water. At $24 \mathrm{~h}$ after inoculation, the roots were

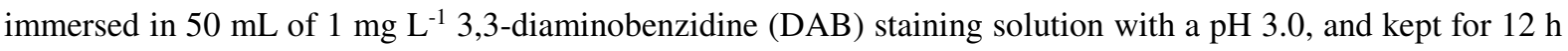
in the dark. Finally, root systems were visualized using a 3D digital microscope (Hirox KH-8700, JP).

\section{Results}

\section{Phenotypic analysis - IAC panel}

Out of 180 accessions from IAC panel, 175 have been successfully evaluated for their sensitivity to RKN. Extensive phenotypic variation was observed within the IAC panel for number of egg masses and root-galling index. The number of egg masses ranged from 1 to 470 with a mean of 142.07, while the mean root-galling index was 2.19 with a range from 0 to 5 (Table 1$)$. 
Table 1 Descriptive summary and variance components of number of egg masses and root-galling index in a common bean core collection and $\mathrm{BC}_{2} \mathrm{~F}_{4}$ population inoculated with $M$. incognita

\begin{tabular}{|c|c|c|c|c|c|c|c|c|}
\hline & & \multirow[b]{2}{*}{ Amplitude } & \multirow[b]{2}{*}{ Mean } & \multirow[b]{2}{*}{$\begin{array}{l}C_{\mathrm{g}} \\
(\%)\end{array}$} & \multicolumn{3}{|c|}{ Variance Components } & \multirow[b]{2}{*}{$\begin{array}{l}H_{c}^{2 \mathrm{a}} \\
(\%) \\
\end{array}$} \\
\hline & & & & & Genetic & Block & Residual & \\
\hline \multirow{2}{*}{ IAC panel } & Egg masses & $1-470$ & 142.1 & 30.71 & 1904.3 & 874.8 & 6178.6 & 48.9 \\
\hline & Root-galling Index & $0-5$ & 2.19 & 23.63 & $2.7 \mathrm{E}-01$ & $7.1 \mathrm{E}-08$ & 7.0E-01 & 55.3 \\
\hline \multirow{2}{*}{$\begin{array}{c}\mathrm{BC}_{2} \mathrm{~F}_{4} \\
\text { population }\end{array}$} & Egg masses & $7-305$ & 90.9 & 36.36 & 1092.6 & 912.6 & 2197.2 & 49.5 \\
\hline & Root-galling Index & $0-4$ & 2.02 & 24.75 & $2.5 \mathrm{E}-01$ & $2.5 \mathrm{E}-02$ & 4.3E-01 & 53.4 \\
\hline
\end{tabular}

${ }^{\mathrm{a}}$ Generalized heritability of Cullis et al. (2006)

The adjusted means of both traits for the core collection (IAC panel) followed continuous distributions and indicated the absence of extreme outliers. In terms of egg masses, 80 genotypes were more susceptible than the average for the panel, and 95 more resistant. However, only three genotypes had adjusted means lower than 100 egg masses. Similarly, in comparison to the mean, 94 genotypes presented weaker symptoms of root-galling, but only 27 had indexes lower than 2.0 and just one scored less than 1.5 (Fig. 1).

Fig. 1 Frequency distribution of the number of egg masses and root-galling index for a common bean core collection (IAC panel) inoculated with $M$. incognita

Respective heritability estimates of 48.9 and $55.3 \%$ were found for egg masses and root-galling (Table 1), indicating that a significant part of the observed variance of response to $M$. incognita might be explained by genetic factors, corroborating the suitability of the core collection for association studies.

A significant genotype effect was confirmed for both traits, according to the LRT results (Table 2), providing further evidence of the existence of a genetic component controlling the response to RKN. Moderate resistance was found in some genotypes, such as IAC-Tybatã and Puebla-152-CIAT with respective adjusted means of 71.6 and 75 for the number of egg masses, whereas other genotypes were highly susceptible, including TB-01-13 and Jamapa-CNF-1671 with respective adjusted means of 246 and 226.1 for the same trait (Online Resource 1).

Table 2 Likelihood ratio test (LRT) and Wald test of random and fixed effects for the number of egg masses and root-galling index of two common bean genetic resources inoculated with $M$. incognita

\begin{tabular}{cccccc}
\hline \multirow{2}{*}{ Genetic Resource } & $\begin{array}{c}\text { Source of } \\
\text { Variation }\end{array}$ & \multicolumn{2}{c}{ Egg masses } & \multicolumn{2}{c}{ Root-galling Index } \\
\hline \multirow{3}{*}{ IAC panel } & Fixed Effects & $\begin{array}{c}\text { Wald } \\
\text { test }\end{array}$ & p-value & Wald test & p-value \\
\cline { 2 - 6 } & Gene Pool & 3.57 & 0.058 & 10.06 & $1.0 \mathrm{E}-02^{*}$ \\
& Random Effects & LRT & p-value & LRT & p-value \\
\cline { 2 - 6 } & Genotype & 39.64 & $3.1 \mathrm{E}-10$ & 49.17 & $2.3 \mathrm{E}-12^{*}$ \\
& Block & 42.87 & $5.8 \mathrm{E}-11$ & $1.0 \mathrm{E}-05$ & 0.99 \\
\hline \multirow{2}{*}{$\mathbf{B C}_{\mathbf{2}} \mathbf{F}_{\mathbf{4}}$} & Random Effects & LRT & p-value & LRT & p-value \\
\cline { 2 - 6 } population & Genotype & 9.67 & $1.9 \mathrm{E}-03$ & 14.36 & $1.5 \mathrm{E}-04^{*}$ \\
& Block & 33.21 & $8 . \mathrm{E}-09$ & 2.56 & 0.109 \\
\hline
\end{tabular}

The Wald test detected a significant gene pool effect for both number of egg masses and root-galling index $(p=0.058$ and $p<0.01$, respectively; Table 2$)$. Although each gene pool exhibited considerable variation, 
the Andean genotypes had higher adjusted means than the Mesoamericans (Online Resource 3). Pearson coefficients revealed that the genotypic correlation between the number of egg masses and root-galling index was 0.61 , suggesting that there may be a relation between the common bean's ability to minimize nematode multiplication and the intensity of observable symptoms in the roots. Root morphology was also examined herein, but no significant correlations were detected between root size and nematode symptoms and signs (Online Resource 4).

\section{Phenotypic analysis $-\mathrm{BC}_{2} \mathrm{~F}_{4}$ Population}

The $\mathrm{BC}_{2} \mathrm{~F}_{4}$ population also exhibited noticeable phenotypic variability, although not as extensive as that observed in the core collection. The number of egg masses and the root-galling index ranged from 7 to 305 and 0 to 4 respectively, with means of 90.9 and 2.02 (Table 1). Moreover, a significant genotype effect was observed for both traits and the generalized measurement of heritabilities for egg masses $(49.5 \%)$ and root-galling index (53.4\%) were also consistent with the results obtained for the IAC panel (Table 1).

Fig. 2 shows the adjusted means for the $\mathrm{BC}_{2} \mathrm{~F}_{4}$ progeny, donor and recurrent genitors, and two resistant and two susceptible controls ranked according to the IAC panel evaluation (Online Resource 1). The recurrent genitor and resistant controls exhibited similar responses to RKN, especially in terms of the number of egg masses. In addition, the donor genitor also did not differ from the susceptible controls with regards to root-galling symptoms, the confidence intervals of several $\mathrm{BC}_{2} \mathrm{~F}_{4}$ individuals did not intersect the mean of the recurrent genitor, indicating transgressive segregation.

Fig. 2 Caterpillar plot of the adjusted means with $95 \%$ confidence intervals for the number of egg masses (a) and root-galling index (b) in a $\mathrm{BC}_{2} \mathrm{~F}_{4}$ population (green) and its donor (And-277; dark red) and recurrent genitors (IAC-Milênio; pink) inoculated with M. incognita. Two resistant (blue) and two susceptible (red) controls are also shown

\section{Genome-Wide Association Studies}

GWAS were conducted with a set of 10,362 SNPs, which were tested against the response to RKN infection taking into account the severity of root-galling and the crop's ability to suppress the production of nematode eggs. According to the quantile-quantile (Q-Q) plots, except for the significant associations that stand out at the high end of the plots, the models used for both number of egg masses and root-galling index presented observed p-values very similar to those that would be expected under the null hypothesis, indicating effective control for false positive associations (Fig. 3b, d).

Fig. 3 GWAS of number of egg masses and root-galling index for the IAC panel inoculated with M. incognita. In the Manhattan plots ( $\mathrm{a}, \mathrm{c})$, the red dashed line indicates the Bonferroni threshold $(\mathrm{p}<4.82 \mathrm{E}-06)$ and the black dashed line denotes the permutation test threshold $(\mathrm{p}<2.29 \mathrm{E}-05$ for egg masses and $\mathrm{p}<1.50 \mathrm{E}-05$ for root-galling index). In the quantile-quantile plots $(b, d)$ the shadow area denotes the $95 \%$ confidence interval

Based on the highly conservative Bonferroni correction, GWAS were able to detect six SNPs significantly associated to RKN resistance, including two for the number of egg masses and four for the rootgalling index. Additionally, when the threshold was defined according to the permutation test, two further SNPs were found associated with the number of egg masses, giving a total of eight significant marker-trait associations (Fig. 3a, c; Table 3). Noteworthy, there were no coincident associations. The four SNPs associated with the 
number of egg masses (S1_257146517, S1_320960286, S1_380326043 and S1_510326192) were located on chromosomes Pv06, Pv07, Pv08 and Pv11 and their effects were -7.6, 13.9, 14.7 and 6.6, respectively. From these, the two SNPs significant according to the Bonferroni threshold (S1_257146517 and S1_320960286) had the highest PVEs (5.37 and 4.57\%; Table 3) and were located at position 48,672,347 bp of Pv07, and 56,279,482 bp of Pv08.

With regards to the root-galling index, the four significant SNPs (S1_46835797, S1_98931885, S1_234697928 and S1_425572688) were located on chromosomes Pv01, Pv02, Pv05, and Pv10. Their effects on the scored index varied from 0.16 (Pv01) to 0.29 (Pv05) and thus explained a higher proportion of variance than those associated with the egg masses, i.e. S1_234697928 and S1_425572688, with PVEs of 7.21 and 9.97\%.

Table 3 Single-nucleotide polymorphism (SNP) significantly associated with the number of egg masses and rootgalling index, according to the GWAS results for IAC panel genotypes inoculated with $M$. incognita

\begin{tabular}{|c|c|c|c|c|c|c|c|c|}
\hline \multicolumn{9}{|c|}{ Egg masses } \\
\hline Marker name & Chr & $\begin{array}{l}\text { Position } \\
\text { (bp) }\end{array}$ & p-value & MAF & $\begin{array}{c}\text { Allelic } \\
\text { reference }\end{array}$ & $\begin{array}{c}\text { Allelic } \\
\text { variant }\end{array}$ & $\begin{array}{l}\text { Effect of the } \\
\text { variant allele }\end{array}$ & $\begin{array}{l}\text { PVE } \\
(\%)\end{array}$ \\
\hline S1_257146517 & $\mathrm{Pv} 06$ & 16835934 & 8.38E-06 & 0.22 & $\mathrm{~T}$ & A & -7.61 & 2.20 \\
\hline S1_320960286 & Pv07 & 48672347 & 3.87E-06 & 0.15 & A & G & 13.92 & 5.37 \\
\hline S1_380326043 & $\mathrm{Pv} 08$ & 56279482 & 4.64E-06 & 0.11 & $\mathrm{C}$ & G & 14.67 & 4.57 \\
\hline S1_510326192 & Pv11 & 45872040 & $1.28 \mathrm{E}-05$ & 0.34 & $\mathrm{~T}$ & A & 6.57 & 2.13 \\
\hline \multicolumn{9}{|c|}{ Root-galling Index } \\
\hline Marker name & Chr & $\begin{array}{l}\text { Position } \\
\text { (bp) }\end{array}$ & p-value & MAF & $\begin{array}{c}\text { Allelic } \\
\text { reference }\end{array}$ & $\begin{array}{c}\text { Allelic } \\
\text { variant }\end{array}$ & $\begin{array}{l}\text { Effect of the } \\
\text { variant allele }\end{array}$ & $\begin{array}{l}\text { PVE } \\
(\%)\end{array}$ \\
\hline S1_46835797 & Pv01 & 46835797 & 7.66E-07 & 0.19 & A & G & 0.16 & 5.52 \\
\hline S1_98931885 & Pv02 & 46726254 & $6.82 \mathrm{E}-07$ & 0.13 & $\mathrm{~T}$ & $\mathrm{C}$ & 0.19 & 5.80 \\
\hline S1_234697928 & $\mathrm{Pv} 05$ & 35206731 & $2.90 \mathrm{E}-11$ & 0.06 & $\mathrm{C}$ & $\mathrm{T}$ & 0.29 & 7.21 \\
\hline S1_425572688 & Pv10 & 4393787 & $7.82 \mathrm{E}-15$ & 0.48 & $\mathrm{~T}$ & G & -0.17 & 9.97 \\
\hline
\end{tabular}

SNPs significantly associated according to the permutation test threshold ( $p<2.29 \mathrm{E}-05$ for egg masses and $p<1.50 \mathrm{E}-05$ for root-galling index) or the Bonferroni multiple test correction ( $\mathrm{p}<4.82 \mathrm{E}-06$ ); Chr: Chromosome; MAF: Minor allele frequency; PVE: Proportion of the variance explained by the SNP-trait association

\section{Validation by QTL mapping}

After evaluating the IAC panel, the phenotypic contrast between genotypes AND-277 and IAC-Milênio was confirmed. These two genotypes were previously used as donor and recurrent genitors for producing a $\mathrm{BC}_{2} \mathrm{~F}_{4}$ population. This population was therefore used to further confirm the loci identified via GWAS. Composite interval mapping was performed using the permutation-based threshold. For the number of egg masses, no QTL was detected. However, one QTL was found controlling the root-galling on chromosome Pv05 at map position $18.6 \mathrm{cM}$ (Table 4; Online Resource 5). This QTL explained 9.24\% of the total phenotypic variance and had an additive effect of -0.17 on the galling index.

Table 4 QTL identified for root-galling index in a $\mathrm{BC}_{2} \mathrm{~F}_{4}$ population inoculated with $M$. incognita

\begin{tabular}{cccccc}
\hline $\begin{array}{c}\text { Nearest } \\
\text { marker }\end{array}$ & Chr & $\begin{array}{c}\text { Map position } \\
(\mathbf{c M})\end{array}$ & LOD & $\begin{array}{c}\text { Effect of the variant } \\
\text { allele }\end{array}$ & $\begin{array}{c}\text { PVE } \\
(\boldsymbol{\%})\end{array}$ \\
\hline Chr05_213377 & Pv05 & 18.552 & 5.14 & -0.17 & 9.24
\end{tabular}

Chr: Chromosome; LOD: Logarithm of odds ratio; PVE: Proportion of the variance explained by the SNP-trait association 


\section{Candidate genes}

Functional mapping of the associated regions can provide valuable indications of which genes or pathways are causally related to the trait. Thus, to establish the size of the genomic regions for candidate gene identification, LD analysis was performed to define the loci in linkage disequilibrium with the SNP associated with egg masses and the root-galling index. These genomic intervals comprised between $89.5 \mathrm{~kb}$ (Pv07) and 306 $\mathrm{kb}(\mathrm{Pv} 11)$ for egg masses and $76.7 \mathrm{~kb}$ (Pv02) and $677.3 \mathrm{~kb}$ for the root-galling index (Pv05; Online Resource 6). Of the 217 genes that we identified in these regions, 216 were functionally annotated, being 125 related to the number of egg masses and 91 to root-galling index (Table S1).

Based on singular enrichment analysis, we contrasted the genome-wide associated regions for both traits and the complete common bean reference genome (Schmutz et al. 2014). In regions related to the number of egg masses, GO terms functionally enriched for biological processes included response to stress and biotic stimulus, defense response, and programmed cell death (PCD) and apoptosis, which were significantly overrepresented (17 to $28 \%$,) when compared with genome-wide annotation (always below 5\%). Similarly, $13 \mathrm{GO}$ terms were enriched for molecular functions, notably those related to ATP- and nucleotide-binding, represented by up to 35\% (Fig. 4a). For the 91 genes annotated in the galling-associated regions, biological process terms were highlighted by protein metabolic processes (28\%), such as proteolysis (11\%) and translation (12\%), while molecular functions related to hydrolase (24\%), peptidase (14\%), and serine-type peptidase activities (10\%; Fig. 4b).

Fig. 4 Singular enrichment analysis of gene ontology (GO) for genomic regions associated with the number of egg masses (blue; a) and root-galling index (blue; b) and their representation in the complete genome annotation background (orange; $a, b)$

To narrow down the number of candidate genes regulating nematode resistance in common bean, we initially referred to a P. vulgaris expression atlas (O'Rourke et al. 2014) and verified that of the 216 annotated genes, 164 are expressed in root tissues (Online Resource 7). Five of these genes were previously reported as differentially expressed during the $P$. vulgaris $-M$. incognita interaction (Santini et al. 2016; Table 5), including four located on root-galling associated regions (Phvul.001G201300, Phvul.005G129600, Phvul.005G130300, Phvul.010G030100) and one on egg mass associated regions (Phvul.008G250700; Table 5). In particular, the genes encoding peroxidase 3-like (Phvul.001G201300), hypersensitive reaction associated ca2+-binding protein (Phvul.005G129600) and serine threonine-protein kinase OXI1-like (Phvul.010G030100) were potentially implicated in defense responses, such as apoptosis, ROS pathways and hypertensive response, corroborating the GO enrichment results (Fig. 4, Table 5).

Table 5 Candidate genes identified by the GWAS-associated genomic regions and differentially expressed in common bean roots at 4 and 10 days after inoculation with $M$. incognita according to Santini et al. (2016)

\begin{tabular}{|c|c|c|c|c|c|c|}
\hline Trait & Associated SNP & Gene ID & $\begin{array}{l}\text { Functional } \\
\text { annotation }\end{array}$ & $\begin{array}{l}\text { Exp. }^{a} \\
4 \text { DAI }\end{array}$ & $\begin{array}{l}\text { Exp. }^{a} \\
10 \text { DAI }\end{array}$ & $\begin{array}{l}\text { Genomic } \\
\text { location }\end{array}$ \\
\hline Egg masses & S1_380326043 & Phvul.008G250700 & $\begin{array}{l}\text { Trans-resveratrol di-o- } \\
\text { methyltransferase-like }\end{array}$ & $*$ & -1.23 & $\begin{array}{c}\text { Pv08:56528566 } \\
. .56529850\end{array}$ \\
\hline Root-galling & S1_46835797 & Phvul.001G201300 & Peroxidase 3-like & 2.638 & $*$ & $\begin{array}{c}\text { Pv01:46687438 } \\
. .46688957\end{array}$ \\
\hline Root-galling & S1_234697928 & Phvul.005G129600 & $\begin{array}{c}\text { Hypersensitive } \\
\text { reaction associated } \\
\text { ca2+-binding protein }\end{array}$ & -1.274 & $*$ & $\begin{array}{c}\text { Pv05:35461253 } \\
. .35462167\end{array}$ \\
\hline
\end{tabular}




\begin{tabular}{|c|c|c|c|c|c|c|}
\hline Root-galling & S1_234697928 & Phvul.005G130300 & $\begin{array}{l}\text { Zinc finger protein } \\
\text { zat5-like }\end{array}$ & 1.645 & $*$ & $\begin{array}{c}\text { Pv05:35542896 } \\
. .35543786\end{array}$ \\
\hline Root-galling & S1_425572688 & Phvul.010G030100 & $\begin{array}{c}\text { Serine threonine- } \\
\text { protein kinase OXI1- } \\
\text { like }\end{array}$ & -1.87 & $*$ & $\begin{array}{c}\text { Pv10:4404524 } \\
. .4406793\end{array}$ \\
\hline
\end{tabular}

${ }^{\mathrm{a}}$ The expression values refer to those reported by Santini et al. (2016) according to $\log _{2}$ fold-change (FC) $\geq 1.0$ and false discovery rate $\leq 0.05$

*Non-significant differential expression

Subsequently, trying to predict the existence of RGAs in the GWAS-associated regions, conserved domains such as NB-ARC, LRR, TM, CC, TIR, Pkinase, and variations were sought. We identified 14 RGAs in five regions, of which 12 were found regions associated with the number of egg masses and two with the rootgalling index (Table 6). Among the 12 RGAs related to egg masses, there is a cluster with six genes encoding a disease resistance protein 1-like predicted on Pv06 (Phvul.006G051500, Phvul.006G052300, Phvul.006G052400, Phvul.006G052500, Phvul.006G052600, Phvul.006G052900). In addition, five Putative disease resistance proteins were identified on Pv11 (Phvul.011G181400, Phvul.011G181500, Phvul.011G181600, Phvul.011G181700, Phvul.011G182300), including a classic TIR-NBS-LRR related to tobacco mosaic virus resistance (TMV Resistance protein N isoform X1). In the root-galling regions, Phvul.010G030100 stands out as a candidate both because encodes a serine threonine-protein kinase OXI1-like and because it was reported as differentially expressed at 4 DAI $\left(\log _{2} \mathrm{FC}=-1.87\right.$; Table 5$)$ by Santini et al. (2016).

Table 6 Resistance gene analogs (RGA) predicted in the GWAS-associated genomic regions, their domains, functional annotation and genomic location

\begin{tabular}{|c|c|c|c|c|}
\hline Trait & RGA ID & Domains $^{a}$ & Functional annotation & Genomic location \\
\hline Egg masses & Phvul.006G051500 & Rx_N, NB-ARC & $\begin{array}{l}\text { Disease resistance protein 1- } \\
\text { like }\end{array}$ & $\begin{array}{c}\text { Pv06:16620561 } \\
. .16623632\end{array}$ \\
\hline Egg masses & Phvul.006G052300 & Rx_N, NB-ARC & $\begin{array}{l}\text { Disease resistance protein 1- } \\
\text { like }\end{array}$ & $\begin{array}{c}\text { Pv06:16682591 } \\
. .16685935\end{array}$ \\
\hline Egg masses & Phvul.006G052400 & Rx_N, NB-ARC & $\begin{array}{l}\text { Disease resistance protein 1- } \\
\text { like }\end{array}$ & $\begin{array}{c}\text { Pv06:16692493 } \\
. .16696743\end{array}$ \\
\hline Egg masses & Phvul.006G052500 & Rx_N, NB-ARC & Disease resistance protein 1 & $\begin{array}{c}\text { Pv06:16711094 } \\
. .16713766\end{array}$ \\
\hline Egg masses & Phvul.006G052600 & Rx_N, NB-ARC & $\begin{array}{l}\text { Disease resistance protein 1- } \\
\text { like }\end{array}$ & $\begin{array}{c}\text { Pv06:16729789 } \\
. .16730533\end{array}$ \\
\hline Egg masses & Phvul.006G052900 & LRR, TM, COR, CC & Protein TRN-1 & $\begin{array}{c}\text { Pv06:16772649 } \\
. .16777588\end{array}$ \\
\hline Egg masses & Phvul.007G246600 & N_T, LRR, TM & Receptor-like protein EIX2 & $\begin{array}{c}\text { Pv07:48600377 } \\
. .48603449\end{array}$ \\
\hline Egg masses & Phvul.011G181400 & TIR, NB-ARC, LRR & $\begin{array}{c}\text { TMV Resistance protein N } \\
\text { isoform X1 }\end{array}$ & $\begin{array}{l}\text { Pv11:45756765 } \\
\quad . .45758261\end{array}$ \\
\hline Egg masses & Phvul.011G181500 & Rx_N, CC, NB-ARC & $\begin{array}{l}\text { Putative disease resistance } \\
\text { protein At3g14460 }\end{array}$ & $\begin{array}{l}\text { Pv11:45766765 } \\
. .45767029\end{array}$ \\
\hline Egg masses & Phvul.011G181600 & Rx_N, NB-ARC, CC & $\begin{array}{l}\text { Putative disease resistance } \\
\text { protein RPP13-like protein } 1\end{array}$ & $\begin{array}{l}\text { Pv11:45768113 } \\
\quad .45772035\end{array}$ \\
\hline Egg masses & Phvul.011G181700 & Rx_N, CC, NB-ARC & $\begin{array}{l}\text { Putative disease resistance } \\
\text { protein At3g14460 }\end{array}$ & $\begin{array}{c}\text { Pv11:45773646 } \\
. .45777320\end{array}$ \\
\hline Egg masses & Phvul.011G182300 & $\begin{array}{l}\text { N_T, LRR, TM, } \\
\text { Pkinase }\end{array}$ & $\begin{array}{l}\text { Leucine-rich repeat receptor- } \\
\text { like protein kinase }\end{array}$ & $\begin{array}{c}\text { Pv11:45895025 } \\
. .45898349\end{array}$ \\
\hline Root-galling & Phvul.001G202600 & F_Box, TIR & $\begin{array}{l}\text { Transport Inhibitor Response } \\
\text { 1-like }\end{array}$ & $\begin{array}{l}\text { Pv01:46818071 } \\
\quad .46823760\end{array}$ \\
\hline Root-galling & Phvul.010G030100 & TIR, NB-ARC & $\begin{array}{l}\text { Serine threonine-protein kinase } \\
\text { OXI1-like }\end{array}$ & $\begin{array}{l}\text { Pv10: } 4404524 \\
. .4406793\end{array}$ \\
\hline
\end{tabular}


${ }^{a}$ Nucleotide binding-ARC (NB-ARC), Leucine-rich repeats (LRR), Transmembrane (TM), Coiled-coil (CC), Toll/interleukin1 receptor (TIR), F-Box protein (F-Box), Resistance protein N-terminal (Rx_N), N-terminal (N_T) and Protein kinase (Pkinase)

\section{Histochemical detection of $\mathrm{H}_{2} \mathrm{O}_{2}$}

In many plant-pathogen interactions, ROS play a key role in the response mechanisms of the host. These molecules act reinforcing the cell wall barrier, inducing direct toxicity and triggering the activation of other defense responses, such as the hypersensitive response (Sato et al. 2019). Histochemical detection of hydrogen peroxide was performed in the roots of contrasting common bean genotypes by staining infected roots with $3,3^{\text {' }-~}$ diaminobenzidine (DAB).

In the histochemical analysis, no marked $\mathrm{H}_{2} \mathrm{O}_{2}$ accumulation was observed in the mock condition (no nematode inoculation). However, at $24 \mathrm{~h}$ after inoculation, we found evidence of greater $\mathrm{H}_{2} \mathrm{O}_{2}$ production in the roots of partially resistant genotypes IAC-Tybatã and Puebla-152-CIAT, compared to the highly susceptible TB01-13 and Jamapa-CIAT-1671, which exhibited no obvious difference from the controls. Interestingly, the moderately susceptible IPR-Saracura also showed modest accumulation (Fig. 5). This result suggests that $\mathrm{H}_{2} \mathrm{O}_{2}$ molecules may act in the common bean response to RKN, possibly involved in resistance mechanisms.

Fig 5 Histochemical detection of hydrogen peroxide $\left(\mathrm{H}_{2} \mathrm{O}_{2}\right)$ in roots of common bean genotypes stained over 12 $h$ with 3,3'-diaminobenzidine (DAB). $\mathrm{H}_{2} \mathrm{O}_{2}$ generated from the roots in response to $M$. incognita oxidizes DAB and produces a dark brown precipitate. The mock column shows non-inoculated roots and the RKN column roots $24 \mathrm{~h}$ after inoculation. Based on the phenotypic analysis, Puebla-152-CIAT and IAC-Tybatã had the lowest number of egg masses while Jamapa-CNF-1671 and TB-01-13 exhibited the highest values. IPR Saracura showed an intermediate response.

\section{Discussion}

Constant screening of gene banks and an understanding of the genetic mechanisms underlying host responses to RKN are essential breakthroughs to identify and characterize sources of resistance and to develop tools to support breeding programs. In nematological studies, the crop responses to RKN are measured by the severity of the symptoms in the roots and the ability of the pathogen to reproduce in the host (Greco and Di Vito 2009). In this study, both responses were covered by assessing the number of egg masses and the root-galling index. We evaluated a core collection panel derived from one of the most extensively used common bean germplasms in Brazil and although complete immunity to nematode infection was not observed, a noticeable variation in RKN sensitivity was verified (Fig. 1). For example, IAC-Tybatã and Puebla-152-CIAT showed moderate resistance, while TB-01-13 and Jamapa-CNF-1671 were highly susceptible to RKN (Online Resource 1). In addition to this panel, we also assessed a BC2F4 population, which despite its modest size, exhibited considerable phenotypic variability. In some genotypes (e.g., 117, 146 and 172) the adjusted means for both rootgalling and egg masses were as low as those for IAC-Tybatã and Puebla-152-CIAT, controls for resistance to $M$. incognita infection (Fig. 2). Our results revealed that variance components and heritabilities were similar for both genetic resources, indicating that the genetic component explains a considerable portion of the phenotypic variance (Table 1).

A positive correlation was detected between egg mass production and severity of root-galling (Online Resource 3), but the interpretation at the biological level of this finding is not straightforward. When nematodes are not able to penetrate the roots there is no galling, but even though the occurrence of galls indicates that RKN 
have invaded the tissue, it does not necessarily imply that they will be capable of laying eggs and satisfactorily reproduce. Furthermore, no swellings are observed in some cases although significant reproduction occurs (Williamson and Roberts 2009). This complex interaction has been studied in many host plants and though there are species in which major resistance genes act to suppress both traits (Roberts 1995), in leguminous crops such as common bean (Fassuliotis et al. 1970; Mullin et al. 1991), soybean (Harris et al. 2003) and lima bean (Roberts et al. 2008) differential responses to root-galling and reproduction have been reported.

When undertaking GWAS, researchers explore LD particularly arising from the physical linkage between genomic markers and the QTLs controlling a given trait. Hence, relatedness among individuals and population structure are often taken into account in the association models in order to control biases and avoid false positive associations (Zhao et al. 2007; Zhang et al. 2010). In a previous study using the same core collection, Diniz et al. (2019) reported that this panel partially consists of improved lines, and therefore the kinship bias on the LD estimates is stronger than the one related to the population structure. The study also revealed that for this panel, population structure bias on the LD is already taken into account when modeling genetic relationships by the kinship matrix, especially since accessions from the same gene pool are closely related. Corroborating these findings, we confirmed herein that when fitting kinship to the association model, low general inflation of p-values was observed, demonstrating goodness of fit and therefore low false discovery rates (Fig. 3b, d).

GWAS analysis identified eight genomic regions with small-to-moderate effects significantly associated with the RKN response, including four for egg masses and four for root-galling index. It denotes the existence of several genes controlling the traits and indicates the complex genetic architecture of the detected resistance. The GWAS results also suggested independent genetic control for each trait, since there were no coincident SNPs significantly associated with egg mass production and the root-galling index. For number of egg masses, significant associations were located on chromosomes Pv06, Pv07, Pv08 and Pv11, whereas for root-galling the associations were on Pv01, Pv02, Pv05 and Pv10 (Fig. 3; Table 3). This result supports the view that the detected correlation among traits is consequence of indirect relationship and corroborates the findings of Roberts et al. (2008), who reported independent genetic control of resistance to root-galling and RKN reproduction in Phaseolus lanatus, which are probably unlinked based on their random assortment in segregating populations.

To validate the GWAS results, we conducted QTL mapping on a $\mathrm{BC}_{2} \mathrm{~F}_{4}$ population. Using the CIM method, we detected one minor QTL on Pv05 for the root-galling index (Table 4). Interestingly, a SNP-galling association on the same chromosome was discovered by the GWAS, but although having comparable effects and PVE, the positions of the QTL and the associated SNPs did not overlap. While the nearest QTL marker was physically located at the beginning of Pv05 (213377 bp), the SNP-association was positioned at the end of the chromosome (35206731 bp). Although the results may suggest distinct QTLs, it is also possible that they are the same, being the discrepancy in their locations ascribed to methodological aspects, such as the design scheme and the small $\mathrm{BC}_{2} \mathrm{~F}_{4}$ population size, which may reflect in substantial within-class variance for QTL mapping and result in limited recombination events, implying low mapping resolution and detection power (Lynch and Walsh, 1998). It can also denote the existence of QTL $x$ environment interaction, as the populations were evaluated independently, or even indicate the presence of a different QTL, as distinct alleles might be responsible for the detected effect in the GWAS panel and in the $\mathrm{BC}_{2} \mathrm{~F}_{4}$ population. In some leguminous crops, such as peanut (Arachis stenosperma), soybean (Glycine max), and especially cowpea (Vigna unguiculata), major QTLs with PVEs higher than those found herein have been associated with resistance to root-galling and egg mass (Caromel 
and Gebhardt 2011; Huynh et al. 2016; Leal-bertioli et al. 2016; Passianotto et al. 2017; Santos et al. 2018; Ndeve et al. 2019). Nevertheless, in terms of aspects such as the complexity of these traits in Phaseolus spp. (Roberts et al. 2008), as well as the phenotyping challenges and the lack of complete immunity, our findings could help to increase selection accuracy in marker-assisted breeding.

Based on the GWAS, we delimitated the genomic regions in LD with the SNP-trait associations and explored candidate genes putatively involved in the suppression of egg mass production and attenuation of rootgalling severity. Singular enrichment analysis showed that for egg masses, the biological process GO terms were functionally enriched for response to stress and biotic stimulus, especially through PCD and apoptosis (Fig. 4). PCD is a common response of plants to pathogens where resistance is conferred by R-genes, which recognize pathogen avirulence genes (Avr) initiating a cascade of signaling processes, that involves major changes in gene expression, oxygen burst and leads to a hypersensitivity response (Dropkin 1969; Bleve-Zacheo et al. 1998; Williamson and Roberts 2009). In tomato, for example, most of the available cultivars contain the R-gene $M i$, which as a RGA encodes a classic cytoplasmatic nucleotide-binding leucine-rich repeat (NB-LRR) protein (Jones and Goto 2011) and confers resistance, though not immunity, to M. incognita, M. javanica and M. arenaria (Milligan et al. 1998; Williamson and Roberts 2009). Several studies have also reported that RGAs are unevenly spread, typically forming complex clusters in plant genomes (Sekhwal et al. 2015), including the P. vulgaris (Schmutz et al. 2014).

Interestingly, in line other nematode resistance genes, presenting typical conserved RGA domains, as NB-LRR (Milligan et al. 1998), in this study 12 RGAs were found in the regions associated to egg mass (Table 6). These genes include a cluster with six genes encoding a disease resistance protein 1-like on Pv06 (Phvul.006G051500, Phvul.006G052300, Phvul.006G052400, Phvul.006G052500, Phvul.006G052600, Phvul.006G052900), a receptor-like protein EIX2 on Pv07 (Phvul.007G246600) and a cluster of five putative disease resistance proteins on Pv11 (Phvul.011G181400, Phvul.011G181500, Phvul.011G181600, Phvul.011G181700, Phvul.011G182300), including a TMV resistance protein N isoform X1, a tobacco mosaic virus (TMV) resistance gene and member of the TIR-NBS-LRR class (Dinesh-Kumar and Baker 2000). Interestingly, two other analogs of the TMV resistance gene ( $\mathrm{N}$ gene) have already been reported as differentially expressed during the P. vulgaris-M. incognita interaction (Santini et al. 2016) and mapped by homology on the same Pv11 chromosome (Santos et al. 2018).

For the root-galling associated regions, biological processes were enriched for terms such as protein metabolic processes, structural functions and organic acids (Fig. 4). With regard to molecular functions, genes such as Phvul.001G202900, Phvul.002G304800, Phvul.005G130900 and Phvul.010G030600, encoding for hydrolases and peptidase (Online Resource 7), may play a role as membrane components and promote cell wall modifications influencing nematode infection and swelling symptoms. Shukla et al. (2018) were able to demonstrate differential regulation of genes encoding cell wall-degrading enzymes and peptidases in a RKNsusceptible tomato. By contrast, the absence of differential expression during the resistance response indicates that these genes are fundamentally involved in cell enlargement and cell wall rearrangement during gall formation, and additionally suggests that RKN effectors might modulate their expression as the disease progresses.

Other remarkable candidate genes located in root-galling regions include two up- and two downregulated during an interaction of a susceptible cultivar at 4 DAI as reported by Santini et al. (2015), three of which are related to protection against oxidative damage. The hypersensitive reaction associated ca2+-binding 
protein (Phvul.005G129600) is an interesting candidate since a $\mathrm{Ca}^{2+}$ influx into the cytoplasm is an early stage response in the signaling pathway of ROS production (Dodd et al. 2010), as has been demonstrated in other Meloidogyne pathosystems (Davies et al. 2015). A second one codes to an enzyme similar to a peroxidase (peroxidase 3-like; Phvul.001G201300), involved in the antioxidant response; and lastly, a RGA annotated as serine threonine-protein kinase OXI1-like (Phvul.010G030100; Table 6), with correspondence to a well-studied gene necessary for oxidative burst-mediated signaling in plants, including defense against root pathogens (Rentel et al. 2004; Petersen et al. 2009).

Histochemical analysis provided preliminary evidence that the accumulation of ROS, specifically $\mathrm{H}_{2} \mathrm{O}_{2}$, is involved in the common bean response to M. incognita, and is higher in the more resistant genotypes (Fig. 5). Our results corroborate those of Melillo et al. (2006), who first demonstrated that the phenotypic expression of complete resistance to RKN in tomato was characterized by a hypersensitive reaction induced by the accumulation of ROS. In a study of leguminous cowpea, Oliveira et al. (2012) reported a higher increase of antioxidant enzymes in resistant genotypes, suggesting higher production and accumulation of $\mathrm{H}_{2} \mathrm{O}_{2}$. In any case, the genotypes investigated herein by histochemical analysis did not exhibit complete immunity, indicating that if the hypersensitivity reaction occurs, as suggested by GO enrichment analysis and gene candidate discovery, it cannot fully prevent nematode invasion and establishment. This absence of typical hypersensitive response was also observed in cowpea, and despite the fact that resistant genotypes present higher ROS accumulation $24 \mathrm{~h}$ after inoculation with M. incognita, there was no characteristic hypersensitive response (Das et al. 2008).

To the best of our knowledge, this is the first study of genetic mapping for RKN resistance in common bean. Results indicate distinct genomic regions associated with egg mass production and severity of root-galling, with complex response mechanisms. In addition, several candidate genes were indicated to putatively control the resistance, including 12 RGAs and five DE genes in common bean roots after inoculation. Thus, validation by fine mapping approaches might provide valuable information for marker-assisted selection and aid breeders to face the challenges imposed by the phenotyping bottleneck (Caromel and Gebhardt 2011), as is already the case for peanut (Chu et al. 2011), cotton (Jenkins et al. 2012) and soybean crops (Dubiela et al. 2019). Finally, functional analysis of the candidate genes will help elucidate the molecular basis of the P. vulgaris-M. incognita interaction and could eventually be used for genetically modifying other related crops.

\section{References}

Abad P, Castagnone-Sereno P, Rosso MN, et al (2009) Invasion, feeding and development. In: Perry RN, Moens CB, Starr JL (eds) Root-knot nematodes, 1st edn. CABI International, London, pp 163-181

Abawi GS, Mullin BA, Maí WF (2005) Diseases caused by nematodes. In: Schwartz HF, Steadman JR, Hall R (eds) Compendium of bean diseases, 2nd edn. American Phytopathological Society Press, St. Paul, pp 5457

Alves FR, Santos LNS dos, Moraes WB, et al (2011) Reaction of common bean genotypes to Meloidogyne incognita Race 1. Idesia 29:95-98. https://doi.org/10.4067/S0718-34292011000200012

Assefa T, Mahama AA, Brown A V, et al (2019) A review of breeding objectives, genomic resources, and marker-assisted methods in common bean (Phaseolus vulgaris L.). Mol Breed 39:1-23. https://doi.org/10.1007/s11032-018-0920-0

Atamian HS, Roberts PA, Kaloshian I, High I (2012) High and Low Throughput Screens with Root-knot Nematodes Meloidogyne. J Vis Exp 61:2-7. https://doi.org/10.3791/3629

Atkinson HJ, Urwin PE, Hansen E, McPherson MJ (1995) Designs for engineered resistance to root-parasitic nematodes. Trends Biotechnol 13:369-374. https://doi.org/10.1016/S0167-7799(00)88983-0

Bellucci E, Bitocchi E, Rau D, et al (2014) Genomics of Origin, Domestication and Evolution of Phaseolus vulgaris. In: Tuberosa R, Graner A, Frison E (eds) Genomics of Plant Genetic Resources, 1st edn. Springer Netherlands, Dordrecht, pp 483-507 
Bitocchi E, Bellucci E, Giardini A, et al (2013) Molecular analysis of the parallel domestication of the common bean (Phaseolus vulgaris) in Mesoamerica and the Andes. New Phytol 197:300-313. https://doi.org//10.1111/j.1469-8137.2012.04377.x

Bitocchi E, Nanni L, Bellucci E, et al (2012) Mesoamerican origin of the common bean (Phaseolus vulgaris L.) is revealed by sequence data. PNAS 109:788-796. https://doi.org/10.1073/pnas.1108973109

Bitocchi E, Rau D, Bellucci E, et al (2017) Beans (Phaseolus ssp.) as a Model for Understanding Crop Evolution. Front. Plant Sci. 8:722-730. https://doi.org/ 10.3389/fpls.2017.00722

Blair MW, Gonza LF, Kimani PM, Butare L (2010) Genetic diversity, inter-gene pool introgression and nutritional quality of common beans (Phaseolus vulgaris L.) from Central Africa. Theor Appl Genet 121:237-248. https://doi.org/10.1007/s00122-010-1305-x

Bleve-Zacheo T, Bongiovanni M, Melillo MT, Castagnone-Sereno P (1998) The pepper resistance genes Me1 and $M e 3$ induce differential penetration rates and temporal sequences of root cell ultrastructural changes upon nematode infection. Plant Sci 133:79-90. https://doi.org/10.1016/S0168-9452(98)00021-1

Bozbuga R, Dasgan HY, Akhoundnejad Y, et al (2015) Identification of common bean (Phaseolus vulgaris) genotypes having resistance against root knot nematode Meloidogyne incognita. Legum Res 38:669-674. https://doi.org/10.18805/lr.v38i5.5948

Bridge J, Page SLJ (1980) Estimation of root-knot nematode infestation levels on roots using a rating chart. Int J Pest Manag 26:296-298. https://doi.org/10.1080/09670878009414416

Broman KW, Wu H, Sen Ś, Churchill GA (2003) R/qtl: QTL mapping in experimental crosses. Bioinformatics 19:889-890. https://doi.org/10.1093/bioinformatics/btg112

Broughton WJ, Hern G, Blair M, et al (2003) Beans (Phaseolus spp.) - model food legumes. Plant Soil 55:55128. https://doi.org/10.1023/A:1024146710611

Butler D, Cullis B, Gilmour A, Gogel B (2009) Analysis of Mixed Models for S-language Environments: ASReml-R Reference Manual. Orange, Australia

Caromel B, Gebhardt C (2011) Breeding for nematode resistance: use of genomic information. In: Jones J, Gheysen G, Fenoll C (eds) Genomics and Molecular Genetics of Plant-Nematode Interactions, 1st edn. Springer, Dordrecht, pp 465-492

Chacón S MI, Pickersgill B, Debouck DG (2005) Domestication patterns in common bean (Phaseolus vulgaris L.) and the origin of the Mesoamerican and Andean cultivated races. Theor Appl Genet 110:432-444. https://doi.org/10.1007/s00122-004-1842-2

Chu Y, Wu CL, Holbrook CC, et al (2011) Marker-assisted selection to pyramid nematode resistance and the high oleic trait in peanut. Plant Genome 4:110-117. https://doi.org/10.3835/plantgenome2011.01.0001

Churchill GA, Doerge RW (1994) Empirical threshold values for quantitative trait mapping. Genetics 138:963971. https://doi.org/10.1534/genetics.107.080101

Conesa A, Götz S, García-Gómez JM, et al (2005) Blast2GO: a universal tool for annotation, visualization and analysis in functional genomics research. Bioinformatics 21:3674-3676. https://doi.org/10.1093/bioinformatics/bti610

Costa JPG da, Soares PLM, Vidal RL, et al (2019) Reaction of common bean genotypes to the reproduction of Meloidogyne javanica and Meloidogyne incognita. Pesqui. Agropecuária Trop. 49:e54008

Coyne D, Affokpon A (2018) Nematode parasites of tropical root and tuber crops (excluding potatoes). In: Sikora RA, Coyne D, Hallman J, Timpper P (eds) Plant parasitic nematodes in subtropical and tropical agriculture, 3rd edn. CAB International, Wallingford, pp 252-289

Cullis BR, Smith AB, Coombes NE (2006) On the design of early generation variety trials with correlated data. J Agric Biol Environ Stat 11:381-393. https://doi.org/10.1198/108571106X154443

Das S, DeMason DA, Ehlers JD, et al (2008) Histological characterization of root-knot nematode resistance in cowpea and its relation to reactive oxygen species modulation. J Exp Bot 59:1305-1313. https://doi.org/10.1093/jxb/ern036

Davies LJ, Brown CR, Elling AA (2015) Calcium is involved in the RMcl(blb)-mediated hypersensitive response against Meloidogyne chitwoodi in potato. Plant Cell Rep 34:167-177. https://doi.org/10.1007/s00299-014-1697-1

Dinesh-Kumar SP, Baker BJ (2000) Alternatively spliced N resistance gene transcripts: their possible role in tobacco mosaic virus resistance. PNAS 97:1908-1913. https://doi.org/10.1073/pnas.020367497

Diniz AL, Giordani W, Costa ZP, et al (2019) Evidence for Strong Kinship Influence on the Extent of Linkage Disequilibrium in Cultivated. Genes 10:1-16. https://doi.org/10.3390/genes10010005

Dodd AN, Kudla J, Sanders D (2010) The Language of Calcium Signaling. Annu Rev Plant Biol 61:593-620. https://doi.org/10.1146/annurev-arplant-070109-104628

Dropkin VHP (1969) The necrotic reaction of tomatoes and other hosts resistant to Meloidogyne: reversal by temperature. Phytopathology 59:1632-1637

Dubiela C, Montecelli TDN, Lazzari F, et al (2019) Development and validation of SNP assays for the selection of resistance to Meloidogyne incognita in soybean. Crop Breed Appl Biotechnol 19:102-109. 
https://doi.org/10.1590/1984-70332019v19n1a14

El-Gebali S, Mistry J, Bateman A, et al (2019) The Pfam protein families database in 2019. Nucleic Acids Res 47:427-432. https://doi.org/10.1093/nar/gky995

Elshire RJ, Glaubitz JC, Sun Q, et al (2011) A Robust, Simple Genotyping-by-Sequencing (GBS) Approach for High Diversity Species. PLoS One 6:e19379. https://doi.org/10.1371/journal.pone.0019379

Faostat (2018) Food and agriculture organization of the united nations statistics division. Crop. Prod. http://www.fao.org/faostat/en/\#data/QC. Accessed 14 May 2020

Fassuliotis G, Deakin JR, Hoffman JC (1970) Root-knot nematode resistance in snap beans: breeding and nature of resistance. J Am Soc Hortic Sci 95:640-645

Gepts P, Aragão FJL, Barros E de, et al (2008) Genomics of Phaseolus Beans, a Major Source of Dietary Protein and Micronutrients in the Tropics. In: Moore PH, Ming R (eds) Genomics of Tropical Crop Plants, 1st edn. Springer New York, New York, pp 113-143

Gepts P, Debouck D (1991) Origin, domestication, and evolution of the common bean (Phaseolus vulgaris L.). In: Voysest O, Schoonhoven A Van (eds) Common beans: research for crop improvement. CABI, Wallingford, pp 7-53

Gepts P, Osborn TC, Rashka K, Bliss FA (1986) Phaseolin-protein Variability in Wild Forms and Landraces of the Common Bean (Phaseolus vulgaris): Evidence for Multiple Centers of Domestication. Econ Bot 40:451-468. https://doi.org/10.1007/BF02859659

Greco N, Di Vito M (2009) Population Dynamics and Damage Levels. In: Perry RN, Moens M, Starr JL (eds) Root-knot nematodes, 1st edn. CABI International, p 246

Hanai LR, De Campos T, Camargo LEA, et al (2007) Development, characterization, and comparative analysis of polymorphism at common bean SSR loci isolated from genic and genomic sources. Genome 50:266277. https://doi.org/10.1139/g07-007

Harris DK, Boerma HR, Hussey RS, Finnerty SL (2003) Additional sources of soybean germplasm resistant to two species of root-knot nematode. Crop Sci 43:1848-1851. https://doi.org/10.2135/cropsci2003.1848

Hoagland DR, Arnon DI (1950) The water-culture method for growing plants without soil. University of California, Berkeley

Huang X, Han B (2014) Natural Variations and Genome-Wide Association Studies in Crop Plants. Annu Rev Plant Biol 65:531-551. https://doi.org/10.1146/annurev-arplant-050213-035715

Huynh B-L, Matthews WC, Ehlers JD, et al (2016) A major QTL corresponding to the $R k$ locus for resistance to root-knot nematodes in cowpea (Vigna unguiculata L. Walp.). Theor Appl Genet 129:87-95. https://doi.org/10.1007/s00122-015-2611-0

Jenkins JN, McCarty JC, Wubben MJ, et al (2012) SSR markers for marker assisted selection of root-knot nematode (Meloidogyne incognita) resistant plants in cotton (Gossypium hirsutum L). Euphytica 183:4954. https://doi.org/10.1007/s10681-011-0470-6

Jones MGK, Goto DB (2011) Root-knot nematodes and giant cells. In: Jones J, Gheysen G, Fenoll C (eds) Genomics and molecular genetics of plant-nematode interactions, 1st edn. Springer, Dordrecht, pp 83-100

Koenig R, Gepts P (1989) Allozyme diversity in wild Phaseolus vulgaris: further evidence for two major centers of genetic diversity. Theor Appl Genet 78:809-817. https://doi.org/10.1007/BF00266663

Koenning SR, Overstreet C, Noling JW, et al (1999) Survey of Crop Losses in Response to Phytoparasitic Nematodes in the United States for 1994. J nema 31:587-618

Koinange EMK, Gepts P (1992) Hybrid weakness in wild Phaseolus vulgaris L. J Hered 83:135-139. https://doi.org/10.1093/oxfordjournals.jhered.a111173

Korte A, Farlow A (2013) The advantages and limitations of trait analysis with GWAS: a review. Plant Methods 9:29. https://doi.org/10.1186/1746-4811-9-29

Kwak M, Gepts P (2009) Structure of genetic diversity in the two major gene pools of common bean (Phaseolus vulgaris L., Fabaceae). Theor Appl Genet 118:979-992. https://doi.org/10.1007/s00122-008-0955-4

Leal-bertioli SCM, Moretzsohn MC, Roberts PA, et al (2016) Genetic Mapping of Resistance to Meloidogyne arenaria in Arachis stenosperma : A New Source of Nematode Resistance for Peanut. G3 6:377-390. https://doi.org/10.1534/g3.115.023044

Lilley CJ, Kyndt T, Gheysen G (2011) Nematode Resistant GM Crops in Industrialised and Developing Countries. In: Jones J, Gheysen G, Fenoll C (eds) Genomics and Molecular Genetics of Plant-Nematode Interactions, 1st edn. Springer Netherlands, Dordrecht, pp 517-541

Lipka AE, Tian F, Wang Q, et al (2012) GAPIT: genome association and prediction integrated tool. Bioinformatics 28:2397-2399. https://doi.org/10.1093/bioinformatics/bts444

Liu X, Huang M, Fan B, et al (2016) Iterative Usage of Fixed and Random Effect Models for Powerful and Efficient Genome-Wide Association Studies. PLOS Genet 12:e1005767. https://doi.org/10.1186/14712156-13-100

Lynch M, Walsh B (1998) Genetics and Analysis of Quantitative Traits. Sinauer Associets, Sunderland, Massachusetts 
Margarido GRA, Souza AP, Garcia AAF (2007) OneMap: software for genetic mapping in outcrossing species. Hereditas 144:78-79. https://doi.org/10.1111/j.2007.0018-0661.02000.x

Melillo MT, Leonetti P, Bongiovanni M, et al (2006) Modulation of reactive oxygen species activities and $\mathrm{H} 2 \mathrm{O} 2$ accumulation during compatible and incompatible tomato-root-knot nematode interactions. New Phytol 170:501-512. https://doi.org/10.1111/j.1469-8137.2006.01724.x

Messeguer R, Ganal M, de Vicente MC, et al (1991) High resolution RFLP map around the root knot nematode resistance gene $(\mathrm{Mi})$ in tomato. Theor Appl Genet 82:529-536. https://doi.org/10.1007/BF00226787

Milligan SB, Bodeau J, Yaghoobi J, et al (1998) The Root Knot Nematode Resistance Gene Mi from Tomato Is a Member of the Leucine Zipper, Nucleotide Binding, Leucine-Rich Repeat Family of Plant Genes. Plant Cell 10:1307-1319. https://doi.org/10.1105/tpc.10.8.1307

Mullin BA, Abawi GS, Pastor-Corrales MA (1991) Modification of Resistance Expression of Phaseolus vulgaris to Meloidogyne incognita by Elevated Soil Temperatures. J Nematol 23:182-187

Ndeve AD, Santos JRP, Matthews WC, et al (2019) A Novel Root-Knot Nematode Resistance QTL on Chromosome Vu01 in Cowpea. G3 9:1199-1209. https://doi.org/10.1534/g3.118.200881

Nyczepir AP, Thomas SH (2009) Management Strategies in Resource-poor Farming. In: Perry RN, Moens M, Starr JL (eds) Root-knot nematodes, 1st edn.CABI International, p 444

O'Leary NA, Wright MW, Brister JR, et al (2015) Reference sequence (RefSeq) database at NCBI: current status, taxonomic expansion, and functional annotation. Nucleic Acids Res 44:733-745. https://doi.org/10.1093/nar/gkv1189

O'Rourke JA, Iniguez LP, Fu F, et al (2014) An RNA-Seq based gene expression atlas of the common bean. BMC Genomics 15:866. https://doi.org/10.1186/1471-2164-15-866

Oliveira JTA, Andrade NC, Martins-Miranda AS, et al (2012) Differential expression of antioxidant enzymes and PR-proteins in compatible and incompatible interactions of cowpea (Vigna unguiculata) and the rootknot nematode Meloidogyne incognita. Plant Physiol Biochem 51:145-152. https://doi.org/10.1016/j.plaphy.2011.10.008

Passianotto ALDL, Sonah H, Dias WP, Abdelnoor R V (2017) Genome-wide association study for resistance to the southern root-knot nematode (Meloidogyne incognita) in soybean. Mol Breed 37:148. https://doi.org/10.1007/s11032-017-0744-3

Perseguini JMCK, Silva GSB, Rosa JRBF, et al (2015) Developing a common bean core collection suitable for association mapping studies. Genet Mol Biol 38:67-78. https://doi.org/10.1590/S1415-475738120140126

Petersen LN, Ingle RA, Knight MR, Denby KJ (2009) OXI1 protein kinase is required for plant immunity against Pseudomonas syringae in Arabidopsis. J Exp Bot 60:3727-3735. https://doi.org/10.1093/jxb/erp219

Petry N, Boy E, Wirth JP, Hurrell RF (2015) Review: The Potential of the Common Bean (Phaseolus vulgaris) as a Vehicle for Iron Biofortification. Nutrients 7:1144-1173. https://doi.org/10.3390/nu7021144

Rentel MC, Lecourieux D, Ouaked F, et al (2004) OXII kinase is necessary for oxidative burst-mediated signalling in Arabidopsis. Nature 427:858-861. https://doi.org/10.1038/nature02353

Roberts PA (1995) Conceptual and practical aspects of variability in root-knot nematodes related to host plant resistance. Annu Rev Phytopathol 33:199-221. https://doi.org/10.1146/annurev.py.33.090195.001215

Roberts PA, Matthews WC, Ehlers JD, Helms D (2008) Genetic determinants of differential resistance to rootknot nematode reproduction and galling in lima bean. Crop Sci 48:553-561. https://doi.org/10.2135/cropsci2007.07.0384

Rodriguez M, Rau D, Bitocchi E, et al (2016) Landscape genetics, adaptive diversity and population structure in Phaseolus vulgaris. New Phytol 209:1781-1794. https://doi.org/10.1111/nph.13713

Rossi M, Bitocchi E, Bellucci E, et al (2009) Linkage disequilibrium and population structure in wild and domesticated populations of Phaseolus vulgaris L. Evol Appl 2:504-522. https://doi.org/10.1111/j.17524571.2009.00082.x

Santini L, Munhoz CDF, Bonfim-Jr MF, et al (2016) Host Transcriptional Profiling at Early and Later Stages of the Compatible Interaction Between Phaseolus vulgaris and Meloidogyne incognita. Nematology 106:282-294. https://doi.org/10.1094/PHYTO-07-15-0160-R

Santos JRP, Ndeve AD, Huynh B-L, et al (2018) QTL mapping and transcriptome analysis of cowpea reveals candidate genes for root-knot nematode resistance. PLoS One 13:1-22. https://doi.org/10.1371/journal.pone.0189185

Santos LNS, Alves FR, Belan LL, et al (2012) Damage quantification and reaction of bean genotypes (Phaseolus vulgaris L.) to Meloidogyne incognita race 3 and M. javanica. Summa Phytopathol 38:24-29. https://doi.org/10.1590/S0100-54052012000100004

Sato K, Kadota Y, Shirasu K (2019) Plant Immune Responses to Parasitic Nematodes. Front Plant Sci 10:11651179. https://doi.org/10.3389/fpls.2019.01165

Schmutz J, McClean PE, Mamidi S, et al (2014) A reference genome for common bean and genome-wide analysis of dual domestications. Nat Genet 46:707-713. https://doi.org/10.1038/ng.3008 
Sekhwal MK, Li P, Lam I, et al (2015) Disease Resistance Gene Analogs (RGAs) in Plants. Int J Mol Sci 16:19248-19290. https://doi.org/10.3390/ijms160819248

Shin JH, Blay S, McNeney B (2006) LDheatmap: An R Function for Graphical Display of Pairwise Linkage Disequilibria between Single Nucleotide Polymorphisms. J Stat Softw 16:1-10. https://doi.org/10.18637/jss.v016.c03

Shukla N, Yadav R, Kaur P, et al (2018) Transcriptome analysis of root-knot nematode (Meloidogyne incognita)-infected tomato (Solanum lycopersicum) roots reveals complex gene expression profiles and metabolic networks of both host and nematode during susceptible and resistance responses. Mol Plant Pathol 19:615-633. https://doi.org/10.1111/mpp.12547

Singh SP, Gutierrez JA, Molina A, et al (1991) Genetic diversity in cultivated common bean: II. Marker-based analysis of morphological and agronomic traits. Crop Sci 31:23-29. https://doi.org/10.2135/cropsci1991.0011183X003100010005x

Singh SP, Schwartz HF (2011) Review: Breeding common bean for resistance to insect pests and nematodes. Can J plant Sci 91:239-250. https://doi.org/10.4141/CJPS10002

Tian T, Liu Y, Yan H, et al (2017) agriGO v2.0: a GO analysis toolkit for the agricultural community, 2017 update. Nucleic Acids Res 45:122-129. https://doi.org/10.1093/nar/gkx382

Trudgill DL, Blok VC (2001) Apomictic, polyphagous, root-knot nematodes: Exceptionally Successful and Damaging Biotrophic Root Pathogens. Annu Rev Phytopathol 39:53-77. https://doi.org/00664286/01/0901-0053

Westermann AJ, Gorski SA, Vogel J (2012) Dual RNA-seq of pathogen and host. Nat Rev Microbiol 10:618630. https://doi.org/10.1038/nrmicro2852

Williamson VM (1998) Root-knot nematode resistance genes in tomato and their potential for future use. Annu Rev Phytopathol 36:277-293. https://doi.org/10.1146/annurev.phyto.36.1.277

Williamson VM, Roberts PA (2009) Mechanisms and genetics of resistance. In: Perry RN, Moens M, Starr JL (eds) Root-knot nematodes, 1st edn. CAB International, Wallingford, pp 301-325

Yaghoobi J, Kaloshian I, Wen Y, Williamson VM (1995) Mapping a new nematode resistance locus in Lycopersicon peruvianum. Theor Appl Genet 91:457-464. https://doi.org/10.1007/BF00222973

Zeng ZB (1994) Precision mapping of quantitative trait loci. Genetics 136:1457-1468. https://doi.org/10.1007/s00122-012-2032-2

Zhang Z, Ersoz E, Lai C-Q, et al (2010) Mixed linear model approach adapted for genome-wide association studies. Nat Genet 42:355-360. https://doi.org/10.1038/ng.546

Zhao K, Aranzana MJ, Kim S, et al (2007) An Arabidopsis example of association mapping in structured samples. PLoS Genet 3:e4. https://doi.org/10.1371/journal.pgen.0030004

Zhu C, Gore M, Buckler ES, Yu J (2008) Status and Prospects of Association Mapping in Plants. Plant Genome 1:5-20. https://doi.org/10.3835/plantgenome2008.02.0089

Online Resource 1 Caterpillar plot of the adjusted means with $95 \%$ confidence intervals for number of egg masses (a) and root-galling index (b) in the IAC common bean core collection including Andean (red) and Mesoamerican (blue) gene pools

Online Resource 2 Linkage map file of a $\mathrm{BC}_{2} \mathrm{~F}_{3}$ population generated by crossing the donor accession AND-277 and the recurrent IAC-Milênio

Online Resource 3 Number of egg masses (a) and root-galling index (b) in common bean genotypes from the Andean (red) and Mesoamerican (blue) gene pools

Online Resource 4 Histograms (diagonal), scatter charts (lower diagonal) and genetic correlations (upper diagonal) for egg masses, root-galling and root morphology traits

Online Resource 5 Logarithm of odds (LOD) scores profile for egg masses (a) and root-galling index (b) according to composite interval mapping using the EM algorithm (red) and Haley-Knot regression (blue) in a $\mathrm{BC}_{2} \mathrm{~F}_{4}$ population. The horizontal dashed lines indicate the permutation threshold

Online Resource 6 Linkage disequilibrium (LD) analysis to define the genomic regions for candidate gene discovery. Significant SNPs and flanking markers in linkage disequilibrium associated with egg masses (a) and root-galling index (b). Heatmap indicates the degree of LD estimates

Online Resource 7 Functional annotation and ontology terms predicted for the candidate genes located in genomic regions significantly associated with egg masses and root-galling index 


\section{Figures}
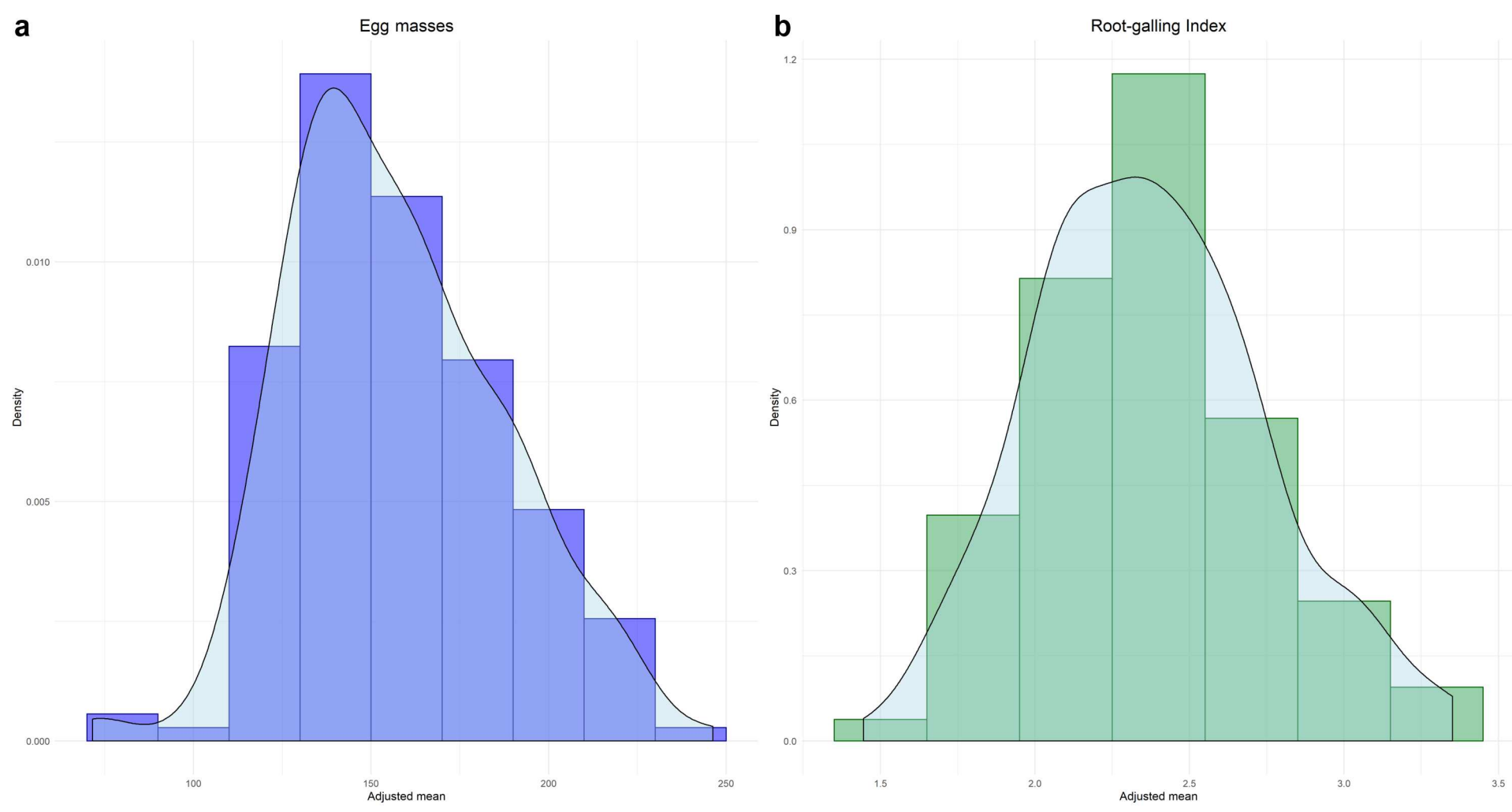

\section{Figure 1}

Frequency distribution of the number of egg masses and root-galling index for a common bean core collection (IAC panel) inoculated with M. incognita 

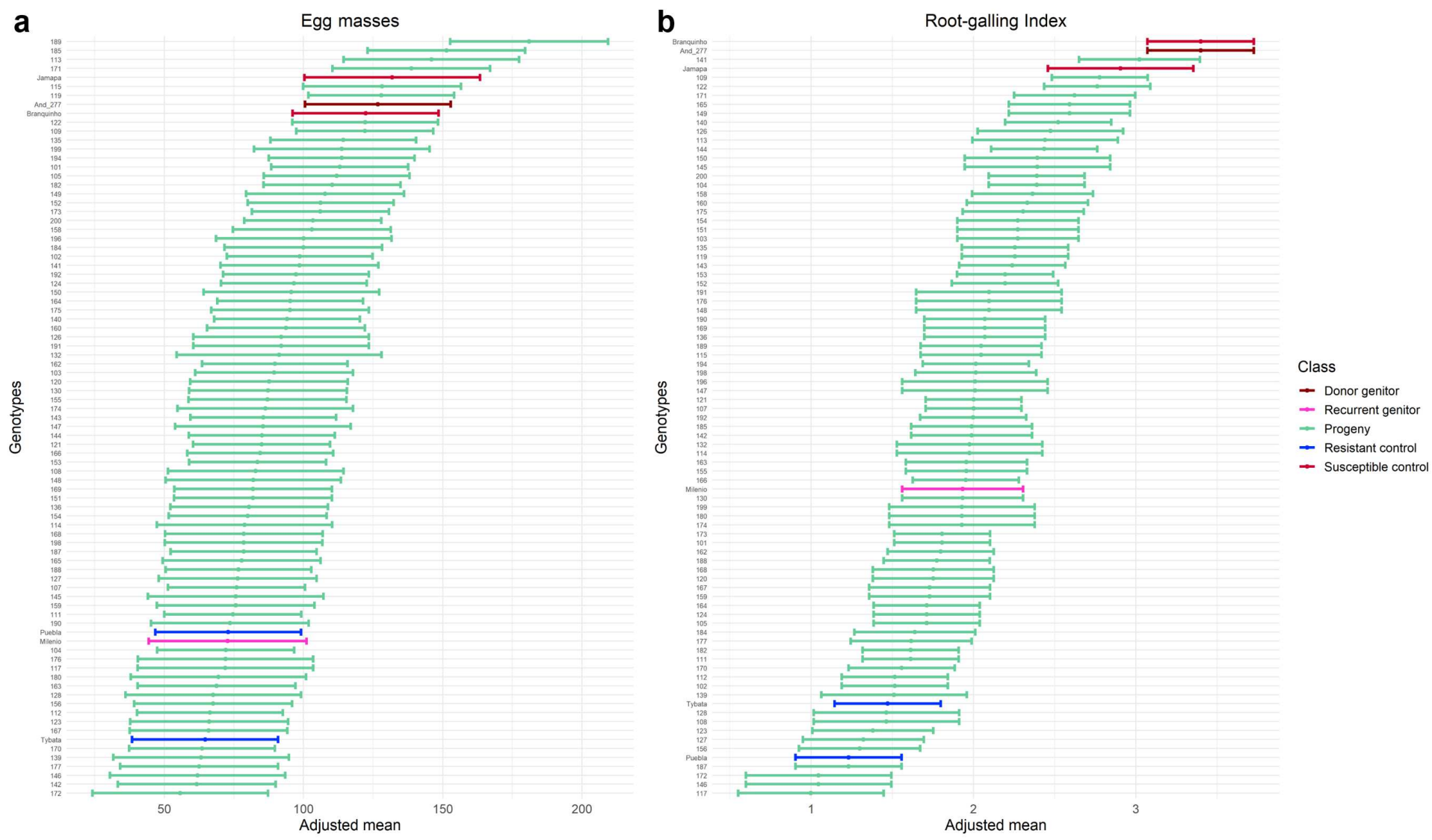

\section{Figure 2}

Caterpillar plot of the adjusted means with $95 \%$ confidence intervals for the number of egg masses (a) and root-galling index (b) in a BC2F4 population (green) and its donor (And-277; dark red) and recurrent genitors (IAC-Milênio; pink) inoculated with M. incognita. Two resistant (blue) and two susceptible (red) controls are also shown 
a
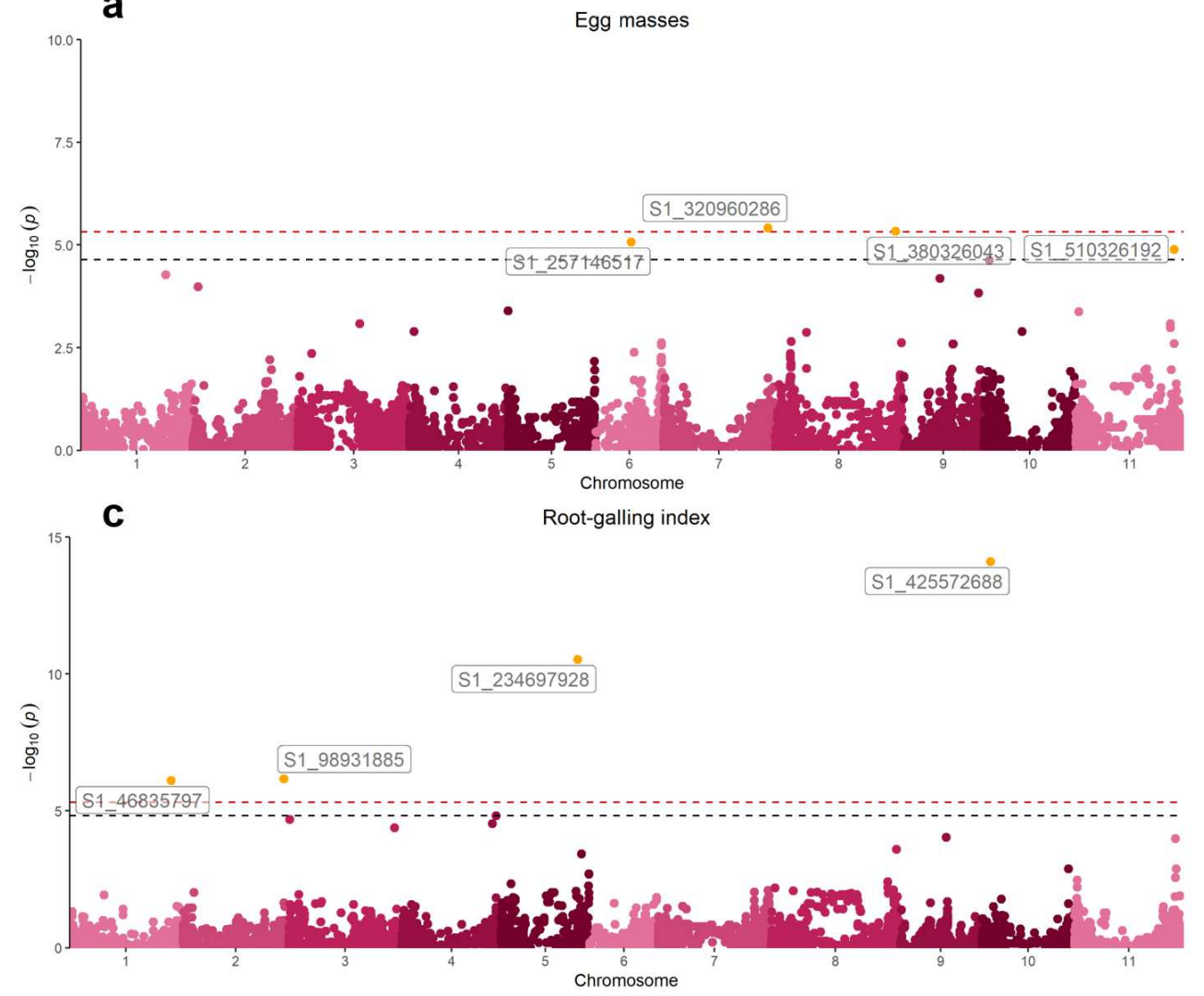

b
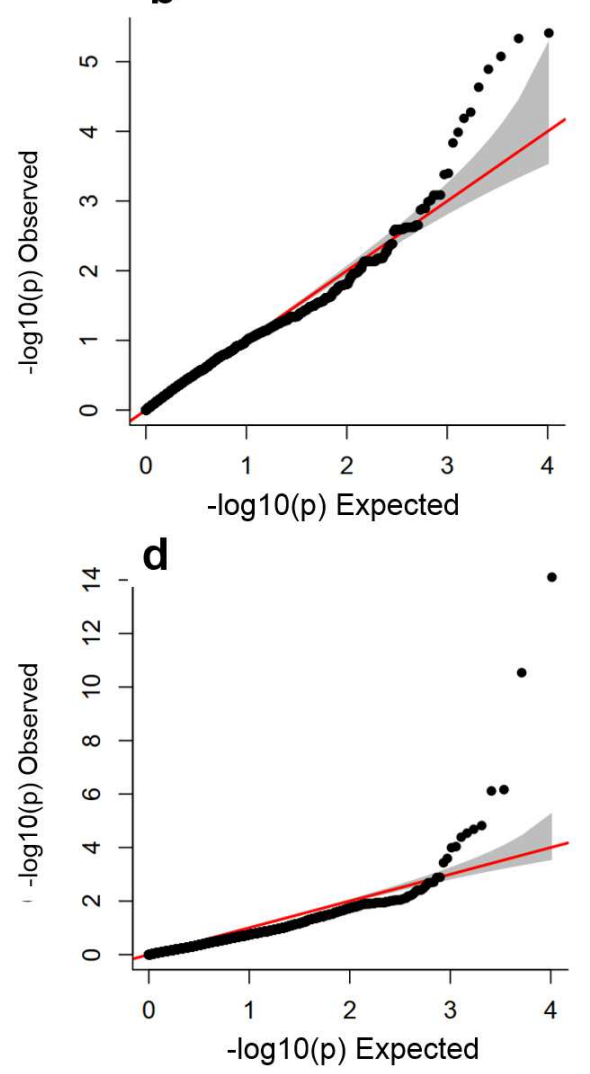

Figure 3

GWAS of number of egg masses and root-galling index for the IAC panel inoculated with M. incognita. In the Manhattan plots $(\mathrm{a}, \mathrm{c})$, the red dashed line indicates the Bonferroni threshold $(\mathrm{p}<4.82 \mathrm{E}-06)$ and the black dashed line denotes the permutation test threshold $(p<2.29 E-05$ for egg masses and $p<1.50 E-05$ for root-galling index). In the quantile-quantile plots (b, d) the shadow area denotes the $95 \%$ confidence interval 
a

Response to stress (GO:0006950)

Response to stimulus (GO:0050896)

Defense response (GO:0006952)

Response to biotic stimulus (GO:0009607)

Apoptosis (GO:0006915)

Programmed cell death (GO:0012501)

Cell death (GO:0008219)

Death (GO:0016265)

ATP binding (GO:0005524) Adenyl ribonucleotide binding (GO:0032559)

Purine nucleoside binding (GO:0001883) Nucleoside binding (GO:0001882)

Adenyl nucleotide binding (GO:0030554) Purine ribonucleotide binding (GO:0032555)

Ribonucleotide binding (GO:0032553)

Purine nucleotide binding (GO:0017076) Nucleotide binding (GO:0000166) ADP binding (GO:0043531) Heme binding (GO:0020037)

Tetrapyrrole binding (GO:0046906) Iron ion binding (GO:0005506)

b

Protein metabolic process (GO:0019538)

Translation (GO:0006412)

Proteolysis (GO:0006508)

Oxoacid metabolic process (GO:0043436)

Carboxylic acid metabolic process (GO:0019752)

Cellular ketone metabolic process (GO:0042180)

Organic acid metabolic process (GO:0006082)

Hydrolase activity (GO:0016787)

Peptidase activity, acting on L-amino acid peptides (GO:0070011)

Peptidase activity (GO:0008233)

Serine-type peptidase activity (GO:0008236)

Serine hydrolase activity (GO:0017171)

Structural constituent of ribosome (GO:0003735)

Structural molecule activity (GO:0005198)
Egg masses

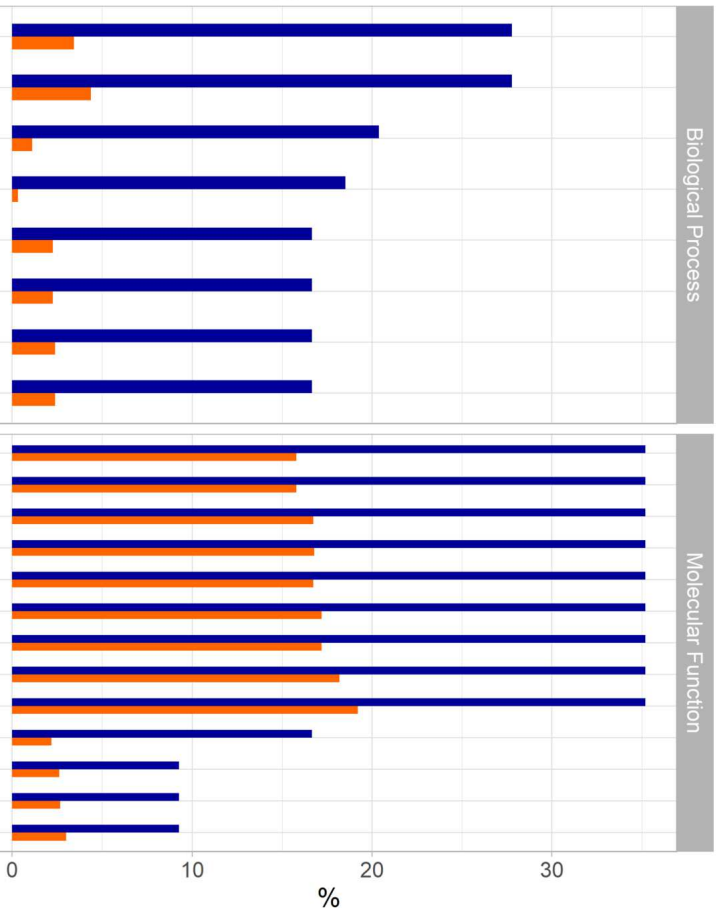

Root-galling Index

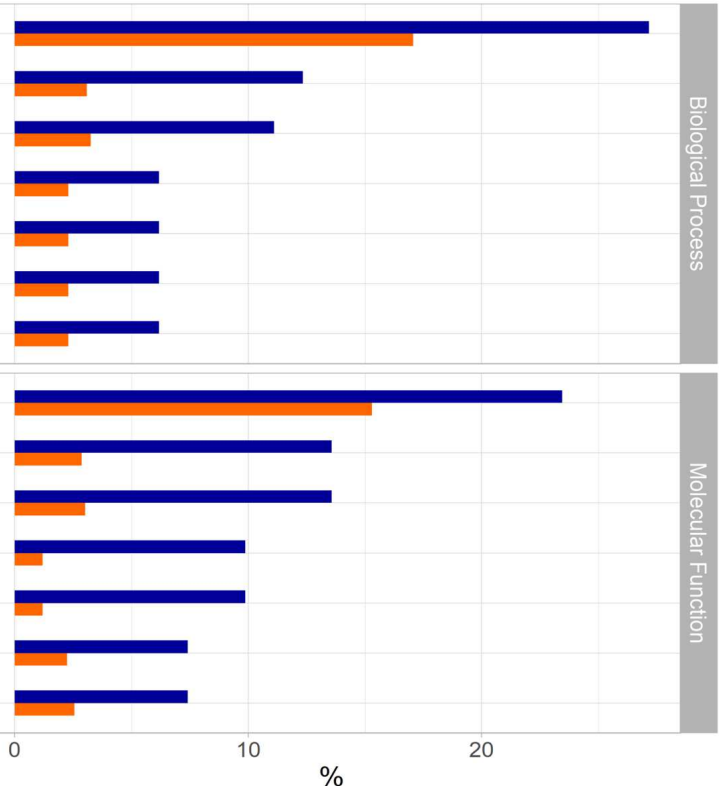

Genome Annotation Background Associated Genomic regions

\section{Figure 4}

Singular enrichment analysis of gene ontology (G0) for genomic regions associated with the number of egg masses (blue; a) and root-galling index (blue; $b$ ) and their representation in the complete genome annotation background (orange; $a, b$ )

4

\section{Figure 5}


oxidizes DAB and produces a dark brown precipitate. The mock column shows non-inoculated roots and the RKN column roots $24 \mathrm{~h}$ after inoculation. Based on the phenotypic analysis, Puebla-152-CIAT and IACTybatã had the lowest number of egg masses while Jamapa-CNF-1671 and TB-01-13 exhibited the highest values. IPR Saracura showed an intermediate response.

\section{Supplementary Files}

This is a list of supplementary files associated with this preprint. Click to download.

- EMS1.tiff

- EMS2.map

- EMS3.tiff

- EMS4.tiff

- EMS5.tiff

- EMS6.tiff

- EMS7.xIsx 